This item was submitted to Loughborough's Research Repository by the author.

Items in Figshare are protected by copyright, with all rights reserved, unless otherwise indicated.

\title{
What determines the likelihood of structural reforms?
}

PLEASE CITE THE PUBLISHED VERSION

http://dx.doi.org/10.1016/j.ejpoleco.2014.10.007

\section{PUBLISHER}

(c) Elsevier

VERSION

AM (Accepted Manuscript)

\section{PUBLISHER STATEMENT}

This work is made available according to the conditions of the Creative Commons Attribution-NonCommercialNoDerivatives 4.0 International (CC BY-NC-ND 4.0) licence. Full details of this licence are available at: https://creativecommons.org/licenses/by-nc-nd/4.0/

\section{LICENCE}

CC BY-NC-ND 4.0

\section{REPOSITORY RECORD}

Agnello, Luca, Vitor Castro, Joao Tovar Jalles, and Ricardo M. Sousa. 2019. "What Determines the Likelihood of Structural Reforms?". figshare. https://hdl.handle.net/2134/25015. 


\title{
What Determines the Likelihood of Structural Reforms?
}

\author{
Luca Agnello $^{\#}$ Vitor Castro ${ }^{ \pm}$João Tovar Jalles ${ }^{+}$Ricardo Sousa ${ }^{\$}$
}

\begin{abstract}
We use data for a panel of 60 countries over the period 1980-2005 to investigate the main drivers of the likelihood of structural reforms. We find that: (i) external debt crises are the main trigger of financial and banking reforms; (ii) inflation and banking crises are the key drivers of external capital account reforms; (iii) banking crises also hasten financial reforms; and (iv) economic recessions play an important role in promoting the necessary consensus for financial, capital, banking and trade reforms, especially in the group of OECD-countries. Additionally, we also observe that the degree of globalisation is relevant for financial reforms, in particular in the group of non-OECD countries. Moreover, an increase in the income gap accelerates the implementation of structural reforms, but increased political fragmentation does not seem to have a significant impact.
\end{abstract}

JEL: Structural reforms, recessions, globalisation, crisis episodes, political setup. Keywords: P11, P16, P34, N20, G28.

\footnotetext{
\# University of Palermo, Department of Economics, Business and Finance, Viale delle Scienze, 90128 Palermo, Italy. Email: luca.agnello01@ unipa.it.

${ }^{ \pm}$University of Coimbra, Faculty of Economics, Av. Dias da Silva, 165, 3004-512 - Coimbra, Portugal; University of Minho, Economic Policies Research Unit (NIPE), Campus of Gualtar, 4710-057 - Braga, Portugal. Email: vcastro@fe.uc.pt.

+ OECD, Economics Department, 2 rue Andre Pascal, 75775 CEDEX 16, Paris, France. Email: joao.jalles@oecd.org.

\$ University of Minho, Department of Economics and Economic Policies Research Unit (NIPE), Campus of Gualtar, 4710-057 - Braga, Portugal. London School of Economics and Political Science, LSE Alumni Association, Houghton Street, London WC2A 2AE, United Kingdom. E-mails: rjsousa@eeg.uminho.pt, rjsousa@alumni.lse.ac.uk.
} 


\section{Introduction}

In the aftermath of the global financial crisis of 2008-2009, the political agenda was dominated by the need to design a response aimed at promoting the economic recovery in the short-term. As financial conditions started to improve, and general economic activity began to show signs of stabilization, policy measures shifted towards a focus on strengthening resilience. Not surprisingly, the implementation of structural reforms is nowadays seen as an important mean for dealing with the negative effects of market failures and the dangers of an opaque regulatory environment, as well as creating the necessary conditions to sustain growth in the medium-term.

In this context, the existing literature suggests that countries are typically induced to implement structural reforms when confronted with a deterioration in economic conditions, i.e. the so called "crisis-induces-reform hypothesis" (Drazen and Grilli, 1993). From a theoretical point of view, crisis episodes are seen as pre-requisites for reform efforts (Bates and Krueger, 1993) or regarded as extreme cases of policy failures (Rodrik, 1996). From an historical perspective, the number of crises experienced by many countries seems to support the argument that crisis episodes facilitate the implementation of structural reforms (Lora and Olivera, 2004; Drazen and Easterly, 2001).

Another strand of the literature highlights the role played by economic growth at fostering structural reforms. For instance, Aghion and Blanchard (1994) show that the restructuring of the state sector depends on labour market conditions. Campos and Horváth (2012a) also emphasize the importance of economic conditions in driving internal and external liberalization reforms and the process of privatization.

Additionally, a number of external, institutional and political factors have been put forward as helping to explain the incentives for reforms. For instance, external aid, whether in the form of a financial assistance program or as part of a sovereign debt restructuring, is normally conditional on the implementation of a series of structural reforms (Drazen, 2000; Fernandez-Arias and Montiel, 2001). Similarly, poor quality of institutions and political fragmentation may deter the course of structural reforms either because of power to block reform legislation (Roubini and Sachs, 1989a), due to the political resistance to changes in the policy process (Alesina and Drazen, 1991; Rodrik, 2000) or even as a reflex of the distributional conflicts at the time of reforms (Rodrik, 1994).

Despite this, the empirical evidence on the "crisis-induces-reform hypothesis" is still scarce or limited to a number of works that provide, at most, some insights on the regulatory 
policy response to crisis episodes (Nelson, 1990; Haggard and Kaufman, 1992), rather than a full assessment of the main drivers of the likelihood of structural reforms.

In this paper, we try to fill the above-mentioned gaps in the literature while answering the following questions: (i) Do crises episodes operate as catalysts of structural reforms? (ii) How important are economic conditions at explaining the implementation of structural reforms? (iii) Can globalisation boost the likelihood of structural reforms? (iv) What is the role played by the political setup?

Using a logistic regression and annual data for 60 countries over the period 19802005, we show that crisis episodes tend to accelerate the implementation of structural reforms. In particular, external debt crises are the main trigger of financial, banking and trade reforms. Inflation and banking crises are key drivers of external capital account reforms. Banking crises also exert an important effect over financial reforms.

Additionally, the empirical findings suggest that a higher degree of globalisation is positively related with most of the reforms implemented by the economies analysed in this study.

Moreover, our findings also show mixed results regarding the intensity of distributional conflicts: a higher degree of inequality pushes forward some reforms, but the fractionalization of the political system is not relevant in the process (with the exception of product market reforms).

Our results are robust even after controlling for the GDP growth and the inflation rate, which has proven to have no significant impact on the kind of reforms analysed in this study (except the positive influence of inflation in fostering capital account restrictions).

We also find that the degree of globalization and the occurrence of crisis episodes are more relevant for the reform effort in non-OECD than in OECD countries. In this last group, recessions are a key catalyst of reforms.

Finally, the empirical evidence reveals that negative changes in the reform indices are better described as "structural reversals" and not as overshoots of the welfare-optimizing points.

The rest of the paper is organized as follows. Section 2 looks at the related literature. Section 3 presents the econometric methodology. Section 4 describes the data. Section 5 discusses the empirical results. Section 6 provides the sensitivity analysis. Finally, Section 7 concludes. 


\section{Literature Review}

A large body of empirical literature considers crises episodes as the key drivers of policy reforms. Haggard and Maxfield (1996) argue that, in response to declining exchange rates, governments are likely to adopt liberal capital account policies to encourage foreign capital owners to resume investment. When capital inflows subsequently resume, exchange rates recover and domestic financial difficulties ease. Similarly, Simmons and Elkins (2004) find a significant and positive effect of currency crises on capital account openness. Moreover, financial liberalization measures consisting of the relaxation of borrowing constraints and the lift of restrictions on cross-border financial transactions often strengthen financial development and contribute to stronger investment and higher long-run growth. The positive direct effect of structural reforms on growth significantly outweighs the growth loss associated with the excessive risk-taking phenomenon induced by liberalization (Ranciere et al., 2006). ${ }^{1}$

Accordingly, countries are typically induced to reform when confronted with deteriorated economic conditions. Episodes of recessions, hyperinflation, fiscal and external imbalances are likely to help removing obstacles to policy changes and to induce reform opportunities (Nelson, 1990; Grindle and Thomas, 1991; Haggard and Kaufman, 1992; Bates and Krueger, 1993; Haggard and Webb, 1994; Williamson and Haggard, 1994). Jong-A-Ping and De Haan (2007) also show that economic reforms lead to accelerations in economic growth and these are more likely when political regimes change.

From a theoretical standpoint, economic stagnation or poor economic prospects that turn into "crises" are seen as pre-requisites for reform efforts. Putting it differently, reforms are not needed when economic conditions are satisfactory (Bates and Krueger, 1993). Indeed, one of the most prominent theoretical argument in favour of the so called "reform-induced crisis hypothesis" concentrates on the public perception of the need of reforms (Williamson, 1994). Only when the economic situation gets quite bad do policymakers realize that there is a permanent problem that requires a major policy change rather than a transitory solution (Tommasi and Velasco, 1996). Along the same line, Rodrik (1994) argues that a crisis can be regarded as an extreme case of policy failure. Thus, if an economy in crisis has not yet reformed, this is because the crisis has not become severe enough. Grier and Sutter (2007) suggest that countries adopt policy reforms in order to increase the returns of and to stimulate

\footnotetext{
${ }^{1}$ Bekaert et al. (2005) find that stock market liberalization leads to an increase of one percentage point on average GDP growth. Levchenko et al. (2010) also uncover positive growth effects when analyzing industry level data. At the firm level, this result is confirmed by Henry (2007) who shows that that financial reforms lead to investment booms associated with declining capital costs.
} 
foreign direct investment. Campos et al. (2010) argue that, more than economic crises, political crises are crucial for structural reforms. Following Rodrik (1996), the authors' reasoning is that, by triggering a re-alignment of the different social groups, political considerations act as catalysts for burden-sharing agreements and, thus, contribute more significantly to the implementation of structural reforms. In addition, they show that, given that labour market liberalisation may be considered more threatening to a larger faction of the population than trade reforms, the impact of political crises tends to be smaller in the case of labour market reforms than for trade reforms. Golinelli and Rovelli (2013) also suggest that the support to structural reforms by citizens is stronger when the economic growth increases and the unemployment rate falls.

Even though crises create conditions under which policymakers are encouraged to undertake extensive policy switches, their effect in stimulating reforms crucially depends on how complex it is to implement them. In particular, the arguments in favour of the "crisisreform" linkages may be weakened when the net cost of reforming is taken into account. Thus, as argued by Drazen (2000), crises may stimulate reforms because the costs of eliminating their causes are low and the benefits are high.

From a historical perspective, the number of crises experienced by many advanced and emerging countries over the last four decades and the variety of regulatory responses to them seem to corroborate the view that crises ease the implementation of reforms (Lora and Olivera, 2004; OECD, 2010).

Nevertheless, the empirical evidence on the "crisis-induced reform" hypothesis is still scarce. So far, only a limited number of works managed to provide insights on the regulatory response to crises and even fewer of them have looked at the policy reform areas in which governments change their reaction to this type of events (Nelson, 1990; Haggard and Kaufman, 1992). Abiad and Mody (2005) find that crisis episodes induce more regulation and fewer reforms. In particular, while balance-of-payments crises spur reforms, banking crises lead to liberalization reversals. Shehzad and De Haan (2009) uncover a negative relationship between financial reforms and the likelihood of systemic crises, conditional on an adequate banking supervision. By contrast, the probability of the occurrence of non-systemic crises rises after the implementation of financial reforms. Agnello et al. (2014a) also show that debt crises promote financial reforms. Babecky and Campos (2011) argue that the inconsistent measurement of reforms can explain the lack of robustness regarding the growth effects of reforms. Campos and Horváth (2012b) examine empirically the determinants of reform reversals. In particular, the authors show that a rise in OECD growth makes external 
liberalization reversals more likely to take place. In the light of "imperfections" displayed by institutions, some authors have also highlighted the need to redefine economic development as being a mix between economic growth and adequate changes in the institutional framework aimed at guaranteeing a sustainable growth (Toye, 1995; Eggertsson, 2005).

Generally, what emerges from this literature is that the crises' characteristics significantly affect the nature and the composition of the reforms. In particular, trade and labour-market reforms are more likely to be prompted by sharp falls in growth and income, while financial reforms tend to follow bouts of high and, especially, volatile inflation, and fiscal crises favour tax reforms (Williamson, 1994; Rodrik, 1994; Elmeskov et al., 1998; Drazen, 2000; IMF, 2004; Boeri et al., 2006). Duval (2008) shows that sound public finances and fiscal expansions foster reforms, with the effect of these being larger for countries with fixed exchange-rate regimes. Wiese (2014) combine a structural break filter and the validation of the structural breaks identified using de jure evidence of reforms in the healthcare sector and find robust evidence of the "reform-induced crisis hypothesis". However, the authors show that political factors do not have a significant impact on this type of reforms. Friedrichsen and Zahn (2014) argue that the economic performance of a country matters even beyond personal economic outcomes. Thus, growing dissatisfaction or lack of political support in hard times typically reflects poor economic conditions and unemployment.

In what concerns the evidence from the debt crises experienced by advanced and emerging countries over the last decades, it suggests that, in most of the cases, the linkages with the implementation of structural reforms crucially depends on whether these are oriented towards sustaining high growth rates in the medium-term and increasing competition in product and labour markets (Nicoletti and Scarpetta, 2003). For instance, some authors uncover the existence of a negative relationship between economic performance and wage rigidities (Bruno, 1986), which appears to be particularly strong in Europe (Koedijk and Kremers, 1996). If past experience provides any guidance for the future, the recent sovereign debt crisis in many EMU countries should indeed serve as a catalyst for reforms.

With regard to economic recessions, Lora and Olivera (2004) find that falling per capita income is the best predictor of economic liberalization as measured by an index of reform which includes financial, labour, privatization, tax and trade reforms. Using a set of structural reform indicators for about 20 Latin American countries over the period 1985-1995, the authors show that crises that are characterized by real income falls and negative growth rates facilitate the adoption of trade reforms (and, to a lesser extent, labour reforms), while inflationary crises tend to be associated with financial reforms. In the same vein, Alesina and 
Drazen (1991) and Drazen and Grilli (1993) argue that growth deceleration may facilitate trade and tax reforms.

As for hyper-inflation episodes, Drazen and Grilli (1993) argue that they provide the incentives for the resolution of social conflicts and, thus, facilitate the introduction of economic reforms and the achievement of higher levels of welfare. Alesina and Drazen (1991) and Drazen and Grilli (1993) find that periods of very high inflation can lead to financial reforms, while fiscal deficits facilitate tax reforms and privatizations. Bruno and Easterly (1996) show that countries experiencing hyper-inflation are more likely to undertake reforms aimed at achieving price stabilization than moderate-inflation countries. Moreover, the authors fail to find similar evidence of the "crisis-induced reform hypothesis" when the crisis is the outcome of a high current account deficit or budget deficit. Drazen and Easterly (2001) report that while hyper-inflation is followed by reforms, public deficit and external imbalances end up attracting foreign aid rather then spurring reforms.

Despite the "crisis-reform" nexus discussed above, it is not sufficient to explain the incentive/opportunity to reform per se. Thus, the political economy literature sheds some light on a number of additional factors (mainly related to the external financing conditions and institutional and political settings) that may influence the likelihood of structural reforms. In this context, foreign financial assistance as typically provided in times of crises by international institutions such as the IMF or bilaterally agreed with foreign governments (e.g. Paris Club) is expected to stimulate reforms. However, as argued by Drazen (2000), Svensson (2000) and Fernandez-Arias and Montiel (2001), financial aid may significantly soften the effects of the crisis, thereby, encouraging governments to postpone the implementation of reforms, especially, those that are particularly challenging to implement (because of market rigidities or political resistance).

In the case of the political and institutional factors, their influence on the policy processes has been extensively studied by Drazen (2000) and Rodrik (2000). For instance, Drazen (2000) points out that economic crises can overcome the resistance to reform by highlighting their need close to the opposition to the government. Rodrik (2000) argues that any kind of policy change significantly depend on the political regime. While in autocratic regimes (such as dictatorships) political opposition to reform is generally repressed, democratic regimes foster economic reforms (Haggard and Kaufman, 1992; Keeler, 1993; Fidrmuc, 2003). Alesina and Drazen (1991) also suggest that reforms are less likely to be implemented (or adopted with delays) in countries with more political fragmentation, where small parties can use their veto power to block reform legislation (Haggard and Webb, 1994; 
Roubini and Sachs, 1989a; Lora, 2000). Similarly, Dollar and Svensson (2000) show that high ethnic fragmentation reduces the probability of a successful implementation of structural reforms. Along the same line, Chang (2001) shows that delays in the path for reform are explained by the need of the government to improve its reputation until the point that reforms are seen as credible, while Tornell (1998) focuses on disruptions between groups and models reforms as costly pre-emptive strikes by one group in the society.

Other authors focus on the relationship between structural reforms (such as privatisations and deregulations) and political ideology, and seem to confirm that right-wing governments are more favourable to such adjustments - i.e. the so called 'partisan effect' (Bortolotti et al., 2003; Bortolotti and Pinotti, 2008; Roberts and Saeed, 2012). Eichengreen and Wyplosz (1998) emphasize that poor public finances make governments less able to undertake structural reforms as a result of the unpopular fiscal adjustment measures that they need to put in place. Yet, financial crises can ease the implementation of fiscal and structural reforms. Persson and Tabellini (2000) show that structural changes towards an increase in fiscal discipline can be boosted by (constitutional) rules, especially, in the case of weak democratic governments. Saint-Paul (2000) highlights that, by reducing rents in one area (of the labour market), the support to structural reforms aimed at reducing such rents in other areas may be dampened. Pitlik and Wirth (2003) find that democratic regimes with fractionalised governments are more prone to have a positive impact on structural reforms. Mierau et al. (2007) suggest an important distinction between fast and slow fiscal adjustments. The authors find that while fast adjustments are only affected by future elections, gradual adjustments are more likely to take place during broad policy reforms. Agnello et al. (2014b) rely on a rare events logit model to assess the impact of fiscal consolidation on the likelihood of financial reforms. They show that spending-driven consolidation measures are more prone towards raising the probability of the implementation of financial reforms than tax-driven austerity measures. Agnello et al. (2014c) stress that despite the negative impact of tax-driven consolidations on unemployment, labour market flexibility can narrow down such effect. Efendic et al. (2011) rely on a meta-regression analysis to assess the linkages between institutions and economic performance. The authors find that, despite the pronounced heterogeneity, the bulk of the evidence suggests the existence of a positive relationship. Tavares (2007) reports an increase in trade liberalization reforms for countries with low quality of customs. De Jong and Bogmans (2011) show that corruption reduces international trade, but bribe paying to customs tends to have a positive effect on imports. Lavigne (2011) investigates the political and institutional determinants of the need of a fiscal adjustment, i.e. 
a period of severe fiscal distress that signals a clear need for fiscal consolidation. The author shows that, in the case of developing countries, a high quality of institutions helps avoiding periods of fiscal distress. For developed economies, budgetary institutions such as fiscal performance management systems make fiscal adjustments more likely to occur when needed. Campos and Horváth (2012a) show that, together with the economic conditions, the level of democracy significantly drives structural reforms, such as internal and external liberalization reforms and privatizations.

Another strand of the literature looks at the spatial aspects of policy adoption. For instance, Case et al. (1993), Grossback et al. (2004) and Volden (2006) suggest that geographically distant states with similar demographics, political ideologies and other characteristics tend to adopt similar policies. Acemoglu et al. (2005) find that policies and institutions where the benefits of the market orientation on countries' growth are more visible are also more likely to be implemented. Volden et al. (2008) present a model of learning and policy choice across governments which shows that policy diffusion generally arises via independent actions taken by governments that only learn from their own experiences. Buera et al. (2011) rely on a learning model to explain the transition of countries between regimes of state intervention and regimes of market orientation. The authors show that such dynamics crucially depends on policymakers' beliefs about the relative merits of the markets versus the state, which are influenced by past experience. Their evidence also supports the idea that countries which are slow to adopt market-oriented policies typically have policymakers who consider that the impact of these policies is country-specific.

Social aspects have also become relevant if we consider the potential distributional effects of the reform process. Alesina and Drazen (1991) argue that reforms that are more subject to political debate (i.e., tax, labor and pension reforms as opposed to financial or trade reforms) are, in general, adopted with a delay. Rodrik (1994) has extensively studied the role of distributional conflict in the timing of reforms. In the author's view, the political cost of a reform is related to the amount of income that is redistributed among different groups, while the benefit comes from the efficiency gains that it produces. The ratio between costs and benefits reflects the degree of political inefficiency of the reform. Along the same line, Roubini and Sachs (1989b) argue that coalition governments are more prone towards higher levels of government spending than majority party governments. This is explained by the fact that parties in a coalition try to ensure higher outlays for their individual constituencies. This argument is assessed empirically by De Haan and Sturm (1997), but their evidence does not seem to support a significant effect of the power dispersion index on the growth rate of 
government debt and the growth rate of government spending. More recently, Agnello et al. (2012) focus on the relationship between financial reforms and income distribution and find a significantly negative link.

Finally, there is another line of investigation that emphasizes the fact that policies and reforms in one country impact other countries' policies and reforms and, thus, cannot be considered isolated. As pointed out by Fidrmuc and Karaja (2013), these works can be clustered into the concepts of reform "contagion", "learning" and "snowballing", where economic reforms are interlinked with waves of political liberalization. For instance, Meseguer (2006) suggests that the existence of a learning process whereby the outcome of reforms (such as central bank independence, IMF agreements, privatizations and trade liberalization) influences the expectations that policy makers have about the effects of similar reforms in their own country. Gassebner et al. (2011) highlight that reform spillovers induced by inter-jurisdictional competition due to factor mobility and cross-country trade and eased by cultural and geographic proximity imply that reforms in a specific countries are a function of reforms in other countries. Brezis and Verdier (2013) show that repressed citizens in a given country are more likely to migrate to neighbouring countries with democratic regimes which, in turn, increases the probability of political liberalization in the first country. Fidrmuc and Karaja (2013) find that informational spillovers facilitate economic and political liberalization. Elhorst et al. (2013) use an error-correction model within a dynamic spatial panel framework and show that the change in the liberalization index of a given country depends not only on the initial level of the index in that country (in line with the works of Abiad and Mody (2005) and Huang (2009)), but also on the financial reforms implemented by other countries (in accordance with the findings of Zandberg et al. (2012)). Moreover, the authors reject the hypothesis of convergence in the extent of financial liberalization among countries.

We try to improve the existing literature along various dimensions. First, our research is related to the work of Abiad and Mody (2005), who focus on the drivers of (large) financial reforms and (large) financial reversals and, thus, consider their various components, such as credit and interest rate controls, entry barriers, international transactions, privatization and regulations. Instead, we assess the determinants of a broader set of structural reforms, namely, financial reforms (and their typologies, such as domestic finance reforms, external capital account reforms and banking sector reforms), trade reforms, capital account restrictions, labour market regulations and product market reforms. 
Second, our work also builds on the "crisis-induces-reform hypothesis" (Drazen and Grilli, 1993). We do so by considering various typologies of crisis episodes, including debt crises (among which domestic debt crisis and external debt crisis), currency crises, inflation crises, and bank crises, as identified by Reinhart and Rogoff (2011). Therefore, our paper is close in spirit with the work of Campos et al. (2010), who also argue that different types of crises have different impacts on the likelihood of structural reforms.

Third, we evaluate the importance of economic conditions, but also a set of institutional and "political" catalysts of structural reforms. Consequently, we rely on the political and institutional data gathered by Beck et al. (2001).

Finally, we also explore the concept of "structural reversals", as captured by negative movement in the relevant structural reform indices, and investigate their main driving forces. As a result, our research is highly indebted to the works of Abiad and Mody (2005), Campos and Horváth (2012a, 2012b) and Campos and Coricelli (2012).

\section{Econometric Methodology}

We employ a logistic regression to assess the determinants of the likelihood of the implementation of a wide set of structural reforms (StruRef). More specifically, we consider the direct impact of crisis episodes (Crisis), economic (Econ) and political ( $\mathrm{Pol}$ ) variables and estimate the following model: ${ }^{2}$

$$
\operatorname{Prob}(\text { StruRef }=1 \mid \text { Crisis, Econ, Pol })=\Phi\left(\lambda_{\mathbf{i}}+\boldsymbol{\alpha} \text { Crisis }+ \text { Econ' }^{\prime} \boldsymbol{\beta}+\operatorname{Pol}^{\prime} \boldsymbol{\varphi}\right),
$$

where $\boldsymbol{\alpha}, \boldsymbol{\beta}$ and $\boldsymbol{\varphi}$ are the vectors of the parameters to be estimated and $\Phi(\cdot)$ is the logistic function. $^{3}$

Given that we rely on panel data, the structural model can be written as:

$$
\begin{aligned}
& \text { StruRef }_{i t}^{*}=\lambda_{\mathbf{i}}+\boldsymbol{\alpha C r i s i s}{ }_{i t}+\operatorname{Eco}_{i t}{ }^{\prime} \boldsymbol{\beta}+\operatorname{Pol}_{i t}{ }^{\prime} \boldsymbol{\varphi}+\varepsilon_{i t}, \\
& \text { StruRef }_{i t}=1 \text { if } \text { StruRef }_{\text {it }}^{*}>0 \text {, and } 0 \text { otherwise. }
\end{aligned}
$$

with $i=1, \ldots, 61 ; t=1980, \ldots, 2005 ; \lambda_{i}$ captures the unobserved individual effects; and $\varepsilon_{i t}$ is the error term.

\footnotetext{
${ }^{2}$ For details on this binary choice model see, for example, Greene (2012, Ch. 17).

${ }^{3}$ We should note that, as probit models do not render themselves well to the fixed-effects treatment due to the incidental parameter problem (Wooldridge, 2002, Ch. 15, p. 484), we estimate a logit model with fixed-effects.
} 


\section{Data}

We start by using a panel dataset consisting of 213 advanced, developing and emerging countries. However, the presence of missing values for several variables and the limited time span of structural reform variables reduce the number of countries in the estimation to a range from 55 to 60 (depending on the type of reform) over the period 19802005. ${ }^{4}$ Table 1 lists the countries included in the sample by set of regressions or type of structural reform.

[Insert Table 1 here]

The data on the main dependent variables encompass the financial sector, the external environment, and the labour and the product markets and can be described as follows:

- the financial sector comprises four main indices: domestic finance liberalization, banking liberalization, international capital flows liberalization and external capital account liberalization. The first two indices are the result of combining a set of other variables including banking supervision and regulation, credit controls, direct credit and reserve requirements, entry barriers, interest rate controls, privatization and securities markets. Each of these is coded from zero (fully repressed) to three (fully liberalized) and is, then, aggregated with equal weights to form domestic finance reforms and banking sector reforms. Together with the liberalization of international capital flows - which qualitatively measures the ease of restrictions of financial credits and personal capital transactions - we obtain an aggregate index of financial reforms (see Abiad and Mody (2005) and Abiad et al. (2008) for details). The external capital account liberalization measures the intensity of legal restrictions on the ability of residents (versus non-residents) to move capital into and out of a country. It is coded from zero (fully repressed) to 50 (fully liberalized) (Schindler (2009)).

- the external environment captures information about average tariff rates. The index is normalized between zero (tariff rates of $60 \%$ or higher) and one (zero tariff rates) and comes from Clemens and Williamson (2004).

\footnotetext{
${ }^{4}$ It is important to highlight that one cannot completely eliminate the data selection problem. Indeed, this econometric issue may still be present because of the reduction in the sample size associated with missing values. For instance, poor quality of institutions may be associated with higher likelihood of crisis episodes. These two characteristics may, in turn, be more important in countries for which data are unavailble or difficult to collect. We thank an anonymous reviewer for emphasizing this relevant issue to us.
} 
- the labour market flexibility index is a weighted average of the following variables: centralized collective bargaining, conscription, cost of hiring, hiring and firing regulations, hiring regulations, mandated cost of worker dismissal and minimum wage. It is standardized to a 0-10 scale, with higher values representing a more rigid labour market, and data are obtained from the Fraser Institute Economic Freedom of the World (EFW).

- the product market index corresponds to the degree of flexibility of agriculture, electricity and telecommunications. It comprises simplified versions of existing indices produced by the OECD and extended in non-OECD countries. Relevant data gathered by the OECD include an index of regulatory reform in the air passenger transport, electricity, gas, post, rail, road freight sectors and telecommunications (Conway and Nicoletti, 2006), and the OECD's Producer and Consumer Support Estimates of agricultural policies during 1986-2006 (which is published as a complement to the OECD report "Agricultural Policies in OECD Countries: Monitoring and Evaluation, 2007").

In order to be able to apply a logit model to this analysis, we start by noting that Abiad and Mody (2005) aggregate six dimensions of financial liberalization to obtain an overall index for each country in each year. By summing those six individual components, which can take on values between 0 and 3, the aggregate index of financial liberalization takes on values between 0 and 18 . Then, the authors classify policy changes for each country-year into five categories: 1) large reversals, i.e. a decrease in the index of 3 or more points; 2) reversals, i.e. a decrease of 1 or 2 points; 3) status quo, i.e. a change in the index between -1 and 1 ; 4) reforms, i.e. an increase of 1 or 2 points; 4) large reforms, i.e. an increase of 3 or more points. Thus, reforms correspond to a change in the financial liberalization index of more than 1 point irrespective of its size on a scale ranging between 0 and 18. That amounts to about more than 0.05 points on a $0-1$ scale. Consequently, we follow the same approach. More specifically, each structural reform index is translated into a binary variable, where a positive movement of more than 0.05 points (in a $0-1$ scale) denotes a reform. This implies that our analysis also imposes a threshold as to which changes of the index are non-trivial and qualify as a reform.

Based on this identification, Table 2 shows the distribution of the various structural reforms considered in the analysis. It can be seen that domestic finance reforms, banking sector reforms and trade reforms are the most frequent ones with $18.0 \%, 17.3 \%$ and $14.8 \%$, respectively, of the total number of episodes identified as structural reforms. By contrast, 
external capital account reforms, financial reforms and capital account restrictions are the least frequent and account for $6.9 \%, 9.8 \%$ and $9.9 \%$ of the total number of structural reforms. Overall, the different structural reforms under consideration are smoothly spread across different typologies.

[Insert Table 2 here]

As for the set of explanatory variables, we consider different types of crisis episodes which are measured as dummy variables taking the value of one when a crisis occurs and zero otherwise. These variables comprise most notably debt crisis (among which we also distinguish between domestic debt crisis and external debt crisis), currency crisis, inflation crisis, and banking crisis. The classification and identification of crises episodes is provided by Reinhart and Rogoff (2011).

The set of economic control variables (Econ) includes: a) the dummy variable, recession, which takes the value of one if the real GDP growth rate is negative and zero otherwise, for which data are retrieved from the World Bank's WDI database; and b) the overall KOF globalisation index as provided by Dreher (2006).

The set of "political" variables ( $P o l)$ includes: a) the Gini coefficient of income inequality; and b) the total fractionalization index i.e. the probability that two random draws would produce legislators from different parties. Both variables proxy for the intensity of distributional conflicts and while the Gini index comes from Standardized World Income Inequality Database (SWIID)), the total fractionalization index is provided by the Database of Political Institutions (DPI) gathered by Beck et al. (2001).

Finally, we note that if crisis episodes are followed by structural reforms, then, including the contemporaneous values of the explanatory variables in our econometric frameworks could imply the existence of endogeneity. ${ }^{5}$ For these reasons, we consider the lag of order one of the explanatory variables in throughout the various regressions.

\section{Empirical Results}

In the Tables of this Section, the first Column presents the results from a general model where we include all economic and political determinants of the likelihood of

\footnotetext{
${ }^{5}$ Indeed, the implementation of structural reforms may lead to a deterioration of specific outcomes in the shortterm, despite their potential improvement over the long-run. In these circumstances, the empirical findings would not be tracking the causal relationship between crisis episodes and structural reforms, but the (immediate) costs of the implementation instead. We thank an anonymous reviewer for pointing this interesting issue to us.
} 
structural reforms, as well as all crisis episodes. In Column 2, we exclude the crisis episodes from the regression, while in Column 3 we consider only the crisis episodes that were statistically significant in the general model (i.e. Column 1). This is our baseline model, as it allows us to understand which types of crisis dominate the implementation of a specific structural reform. In Column 4, we investigate the existence of a nonlinear relationship between economic conditions and the likelihood of the implementation of structural reforms and, thus, control for the effect of GDP growth by replacing the dummy variable Recession with the GDP growth and its square in the set of regressors. ${ }^{6}$ In Column 5, we test whether inflation creates a disincentive for the implementation of structural reforms. ${ }^{7}$ To do so, we augment our baseline model by including the inflation rate as measured by the annual percentage change in the CPI (source: World Bank's WDI dataset). Finally, in Columns 6-7, we re-estimate the baseline model for developed (OECD) and developing (non-OECD) countries, respectively. In this way, we assess the extent to which our conclusions are similar among different groups of countries.

\subsection{Financial Reforms}

We start by analysing the determinants of the probability of implementing a financial reform.

Our results are summarized in Table 3. By improving growth prospects, financial sector reforms may help mobilizing savings (and, consequently, expanding the availability of credit in the economy), but also improving capital allocation (Henry, 2007). These positive aspects tend to outweigh the increasing risk-taking behaviour associated with financial liberalization (Ranciere et al., 2006). Our findings suggest that financial reforms are speeded

\footnotetext{
${ }^{6}$ From a theoretical point of view, Aghion and Blanchard (1994) argue that when the level of unemployment is low, an increase in unemployment induces more job creation. By contrast, when unemployment is high, a rise in unemployment may lead to the destruction of job creation. As a consequence, structural reforms - and, in particular, the restructuring of the state sector - are possible only with the support of the insiders and, thus, depend on labour market conditions in that a high unemployment can hinder structural reforms. Similarly, Fernandez and Rodrik (1991) show that, rather than hysteresis due to sunk costs, irrationality or risk aversion, it is the uncertainty about the distribution of the gains and losses from reforms that can lead to a bias towards the status quo. From an empirical perspective, Campos and Horváth (2012a) develop some improved measures of economic liberalization across countries and over time and, relying on a set of transition economies, they show that structural reforms display a richer dynamics than the one suggested by previous indices. Among the set of potential determinants of reforms, these authors consider the economic conditions and, thus, control for changes in the GDP growth and the unemployment rate. Bates and Krueger (1993) also argue that there is no need for reforms at the time when economic conditions are "reasonably" satisfactory.

${ }^{7}$ The dynamics of GDP growth and inflation are generally linked and there has been a considerable debate on the nature of their relationship. Indeed, apart from episodes of very "high" and/or very "low" inflationary pressures which are likely to have distortional effects on long-term economic growth whose impacts are difficult to discern (Bruno and Easterly, 1996; Blanchard et al., 2010), inflation typically falls during recessions and increases over expansions (or economic recoveries).
} 
up when economic conditions deteriorate. In fact, it is during periods of recession that countries are more prone to make the necessary financial reforms (Nelson, 1990; Bates and Krueger, 1993; Williamson and Haggard, 1994). This result has proven to be more evident in the group of OECD-countries than in the other. In this context, Krueger (1993) states that reforms are undertaken only when the economic environment sufficiently deteriorates and triggers a political imperative for pursuing a (long-lasting) better economic performance (Tommasi and Velasco, 1996).

The degree of globalisation or openness to international trade is also fundamental for this kind of reforms ${ }^{8}$ in this case, it is the most important factor for the group of non-OECD countries. Saint-Paul (2004) suggests that the increase in trade openness and the subsequent rise in the elasticity of labour demand in small open economies narrow the ability of insiders to set higher-than-equilibrium wages. This, in turn, generates lower rents and raises the public support for institutional changes. Given that these countries' financial systems are usually under-developed and constrained by underlying structural weaknesses, the more closed they are, the more difficult it will be for them to implement the necessary reforms in their financial system. When they are more open and integrated in the global market chain, stronger competition pushes them to make the necessary reforms to cope with demand pressures from the more developed markets.

Regarding the proxies for the intensity of distributional conflicts (Gini and fractionalisation), results are weak, in the sense that only a higher inequality in the distribution of income has a marginally significant impact on the likelihood of financial reforms. Despite this, the evidence suggests that increasing inequality may trigger financial reforms. By fuelling political disaffection, income inequality is typically seen as being at the roots of political instability (Agnello et al., 2014d). More specifically, when the income gap rises, the increased social pressure and discontentment tend to lead to unstable political environments, therefore increasing the likelihood of a government crisis. This, in turn, paves the way for governments to pursue long-delayed reforms.

Some crises have also proven to hasten financial reforms. We find a positive and significant impact, especially in the case of external debt and banking crises. Among other

\footnotetext{
${ }^{8}$ Several channels can explain the link between structural reforms and the degree of openness of a country: (i) higher openness can act as an automatic stabiliser as it reduces the impact of any reform-driven change in domestic demand; (ii) trade openness can amplify the net external demand gains from reforms that lower domestic prices and improve external competitiveness, helping to crowd-in demand in small open economies; and (iii) insofar as the real exchange rate depreciates and causes a terms of trade loss, the related negative impact on household's consumption can be larger in more open economies, where imports represent a bigger share of domestic demand (Gomes et al., 2011).
} 
episodes, banking crises are particularly prone at promoting financial reforms, albeit the estimated coefficient is similar to the one associated with external debt crises. This is an important result that finds support in the works of Drazen and Grilli (1993), and Drazen and Easterly (2001), who show that crises can promote economic reforms (Alesina and Drazen, 1991; Lora and Oliveira, 2004). ${ }^{9}$ This is particularly true in the group of non-OECD countries. As their institutional framework is traditionally underdeveloped, debt and banking crises will uncover their weaknesses and force these countries to implement the necessary financial reforms.

Finally, the empirical evidence indicates that economic growth and its square do not per se drive the implementation of financial reforms. In fact, the coefficient associated to GDP growth is not statistically significant. Additionally, the statistical significance of its square is not supportive of the nonlinearity hypothesis. Similarly, the inclusion of inflation does not significantly affect the likelihood of structural reforms.

[Insert Table 3 here]

\subsection{Financial Restrictions}

Turning to the financial sector's disaggregation, we now look more closely at the domestic finance, international capital flow and banking indices. Our results are displayed in Tables 4, 5 and 6, respectively.

Table 4 shows that the outcome of a debt crisis (especially of an external nature) is a reasonable boost to the likelihood of a domestic financial reform: the coefficient associated with debt crises is positive (0.6-0.7) and statistically significant. The other types of crisis episodes have not proven to be relevant to this kind of reform. Moreover, similarly to overall financial reforms analysed above, domestic financial reforms are also hasten when economic conditions deteriorate, i.e. when a country displays negative growth, especially if it belongs to the group of OECD-countries. The degree of globalisation is another influential factor for this kind of reforms, once again, with particular emphasis in the group of non-OECD countries.

We also find that a deepening of the intensity of distributional conflicts - especially when proxied by the Gini coefficient - makes domestic financial reforms more prone to take place. Thus, an increase in inequality will promote social instability and generate a general discontentment which might lead to political instability. Hence, this environment will increase

\footnotetext{
${ }^{9}$ Williamson and Haggard (1994) also points to several examples of reforms that were undertaken in the past despite the absence of a crisis (notably, in Australia, Colombia and Portugal).
} 
the likelihood of government crises, forcing governments to implement these domestic financial reforms, independently of the level of fractionalisation of the political system.

Our new set of findings also corroborate that economic growth, its square and the inflation rate do not have a significant impact on the implementation of domestic financial reforms. Moreover, results remain both quantitatively and qualitatively unchanged, confirming our previous conclusions.

\section{[Insert Table 4 here]}

With regard to external capital account reforms, the empirical evidence suggests that debt crises (irrespectively of their nature) and currency crises do not seem to foster such type of liberalization processes, whereas banking and inflation crises do (Table 5). Indeed, while the coefficients associated with debt and currency crises are not significant, those associated with banking crises and inflation crises are positive and statistically significant ( 0.83 and 0.57 , respectively), in line with Alesina and Drazen (1991) and Drazen and Grilli (1993). These effects are stronger in the group of non-OECD countries. Price increases are usually associated with worsening inequality and poverty levels since, by adding economic uncertainty, they erode the incomes of the poorest and limit their ability to borrow and smooth consumption over the life cycle (Romer and Romer, 1999; Easterly and Fisher, 2000). In particular, hyper-inflation episodes lead independent central banks to tighten the monetary policy stance by raising the interest rate and, thereby, inverting the declining movement in exchange rates and attracting foreign investors' capital to resume investment domestically (Haggard and Maxfield, 1996). In fact, countries that experienced hyper-inflation conduct policy reforms aimed at regaining price stabilization (Bruno and Easterly, 1996). Moreover, such episodes are usually associated with the liberalization of external capital account directives and this helps explaining the positive impact that we find on this type of reforms.

Periods of recession are still presenting some influence on this kind of reforms, but only marginally. However, a higher degree of globalisation, distributional conflicts and inflation do not seem to have any significant impact on external capital account reforms. In the case of GDP growth, the coefficient is negative. This is consistent with the idea that during bad times, the probability of implementing reforms increases.

[Insert Table 5 here] 
Banking sector reforms - summarized in Table 6 - appear to be particularly sensitive to the occurrence of external debt crises: the coefficient associated with this dummy variable is positive (0.62) and statistically significant. This result is somewhat in contrast with the work of Abiad and Mody (2005), who find a negative impact of banking crises on financial liberalization and, thus, suggests that an increase in the government control of the financial sector is typically a temporary response to this type of crisis. In particular, we observe that external debt crises exert pressure on the banking sector, which ultimately forces it to engage in the necessary reforms.

In line with the results for financial reforms, the empirical evidence suggests that periods of negative growth, especially in OECD countries, make the implementation of banking reforms more likely to take place. A higher degree of globalisation has the same effect, and non-OECD countries seem to be the ones that benefit the most from international integration. A similar conclusion is obtained when we look at the results for the coefficient on the Gini index: there is evidence supporting the role played by distributional issues on the probability of a banking reform. Although this type of reforms normally takes place under the supervision of a central bank or independent supervisory regulator and, thus, are more likely to be adopted without delays (Alesina and Drazen, 1991), we are able to uncover this positive effect of income inequality. In fact, worse income distribution tends to raise the social and political consensus for banking reforms, which seem to be most required in the group of nonOECD countries.

[Insert Table 6 here]

\subsection{Trade Reforms, Capital Account Restrictions, Labour Market Regulations and Product Market Reforms}

Additionally, we also explore the impact of crises on trade reforms, capital account restrictions, labour market regulations and product market reforms. The results are presented in Tables 7 to 10, respectively, but little statistically significant effects are found. In particular, crises do not appear to contribute to the implementation of any of these reforms. Only periods of negative growth and inflation have a positive impact on trade reforms. Capital account restrictions are only marginally positively affected by the fractionalisation of the political system and negatively by the GDP growth, but labour market regulations and product market reforms seem to be exogenous to crises and, more generally, to economic and political factors. Nevertheless, product market reforms are hastened by political 
fractionalisation in OECD countries, while increased income inequality speeds up these reforms in non-OECD countries.

\author{
[Insert Table 7 here] \\ [Insert Table 8 here] \\ [Insert Table 9 here] \\ [Insert Table 10 here]
}

\title{
6. Sensitivity Analysis
}

In order to assess the sensitivity of our results, we carry out two main robustness checks. First, we test whether structural reversals are linked to the same factors explaining the reform process (section 6.1). Second, we estimate our models via Instrumental Variable (IV) techniques so as to overcome potential endogeneity issues (section 6.2). ${ }^{10}$

\subsection{Structural "reversals"}

So far, our study has focused on the economic and political drivers of structural reforms. However, attaining the highest possible value of each index may not be necessarily always optimal. More generally, knowing which factors induce reform reversals may also be interesting from a policy perspective.

In this context, Dewatripont and Roland (1995) and Alesina and Drazen (2001) investigate the political economy of reform packages that have a low probability of reversal. Abiad and Mody (2005) show that crises episodes typically lead to more regulation and less reform. More specifically, crises in the balance-of-payments tend to foster reforms, while banking crises are more prone to generate reversals of liberalization processes. The authors also find that the general trend towards liberalization is associated with pressures and incentives generated by initial reforms, which increase the need for additional reform and stimulate the catching-up with reform leaders. Campos and Horváth (2012b) investigate the factors that determine the probability of reform reversals. In particular, the authors show that: (i) foreign direct investment makes reversals of privatization less likely to happen; (ii) a

\footnotetext{
${ }^{10}$ We have also estimated a dynamic probit model using a system-GMM framework. The empirical findings suggest that the coefficient associated with the lagged dependent variable is statistically significant in five out of eight structural reforms. Moreover, the estimates are relatively small in magnitude. This implies that the "longterm" and the "short-term" effects of the various regressors on the dependent variable are very close to one another. As a result, the likelihood of the implementation of a structural reform does not display substantial inertia and the estimation of a dynamic probit model does not qualitatively and quantitatively change our main conclusions. These results are available upon request.
} 
deterioration of the terms of trade and a rise in OECD growth has a positive impact on the probability of external liberalization reversals; and (iii) labour strikes raise the likelihood of reversals of price liberalization. Campos and Coricelli (2012) identify the political regime as one of the main drivers behind the dynamics of financial reforms. Indeed, the authors show that partial democracy is a main obstacle to financial reforms. Moreover, when incomplete, democratization can cause severe reversals of financial reforms.

In order to explore this issue, we formulate the definition of "structural reversals". Specifically, each structural reform index is translated into a binary variable, where a negative movement denotes a structural reversal, in line with the works of Abiad and Mody (2005) and Abiad et al. (2008). Then, we estimate our baseline model for each type of structural reversal.

Our results are reported in Table 11 and suggest that episodes of negative growth have a significant impact on financial, domestic finance, external capital account, banking and capital account reversals, but no impact in the other cases. At the same time that periods of economic downturns can spur consensus for a reform, they also contribute to a reversal due to the deterioration of the economic conditions. Product market reversals are only affected by a higher degree of globalisation, which may be due to the influence of external spillovers that undermine the underlying domestic structure of more fragile countries.

When we look at the impact of the intensity of distributional conflicts, we find that income inequality affects negatively the likelihood of financial, domestic finance and banking reversals, which is consistent with the fact that inequalities generally lead to reforms and not to structural reversals. The fractionalisation of the political systems remains irrelevant even for structural reversals.

Finally, we observe that crises do not have any impact on structural reversals. Comparing this evidence with the one we obtained above for reforms, we conclude that crises have the characteristic of promoting/hastening reforms and never reversals.

All in all, the lack of statistical significance of a large number of variables (when compared to our evidence regarding the likelihood of structural reforms) suggests that negative changes in the reform indices are better described as "structural reversals" rather than overshoots of the welfare-optimizing points (in which case they would be seen as reforms).

[Insert Table 11 here] 


\subsection{IV/Endogeneity}

We also estimate the baseline models using an IV-probit estimator where the endogenous regressors are instrumented with their own lags. The results reported in Table 12 are obtained considering that recessions may be endogenous. Two lags are used in the different estimations, however, exogeneity tests show that we cannot reject the null hypothesis. ${ }^{11}$ Even though results for economic and political conditions are weaker, we still confirm the important impact that crises have on financial reforms, domestic finance reforms, external capital account reforms and banking reforms. It can be seen that the coefficients on these variables keep the same statistical significance and sign. Therefore, the empirical evidence is robust to the use of different estimation techniques.

[Insert Table 12 here]

\section{Conclusion}

In this paper, we use data for a panel of developed and developing countries to assess the impact of crisis episodes on the likelihood of structural reforms. We find that: (i) external debt crises are the main trigger of financial, banking and trade reforms; (ii) inflation and banking crises are the key drivers of external capital account reforms; (iii) banking crises also hasten financial reforms; and (iv) economic recessions play an important role in promoting the necessary consensus for financial, capital, banking and trade reforms, especially in the group of OECD-countries.

Additionally, we show that the degree of globalisation is fundamental for financial reforms, in particular for non-OECD countries, as well as trade reforms. Moreover, by making distributional conflicts more intense, an increase in the income gap has also proven to accelerate the implementation of structural reforms. Furthermore, increased political fragmentation speeds up the implementation of product market reforms, particularly in OECD countries.

Our results are generally robust when controlling for either the GDP growth or the inflation rate, exploring different sub-samples (OECD versus non-OECD countries) and accounting for potential endogeneity concerns. They also suggest that a "downgrade" of the reform indices is better characterized as a "structural reversal" and not as an overshoot vis-à-

\footnotetext{
${ }^{11}$ As we use lags of the regressors to avoid simultaneity problems, the only explanatory variable that remains likely to present some endogeneity is Recession. Nevertheless, results support the hypothesis that it is exogenous. The same conclusion is obtained when other variables are assumed to be endogenous (results not reported here for reasons of parsimony).
} 
vis some optimal level (in which case, the negative change in the reform indices would be interpreted as a "reform").

In addition to providing valuable information about the impact of different crises on the probability of the implementation of structural reforms, this paper opens new avenues for further work. For instance, one may want to assess the extent to which crises can act as catalysts of institutional changes. We leave this question for future research.

\section{References}

Abiad, A., and A. Mody, 2005. Financial reform: What shakes it? What shapes it? American Economic Review, 95(1), 66-88.

Abiad, A., Detragiache, E., and T. Tressel, 2008. Do financial reforms boost the development of financial systems? Evidence from a new database on financial reforms. International Monetary Fund, IMF Working Paper No. 265.

Acemoglu, D., Johnson, S., and J.A. Robinson, 2005. Institutions as the fundamental cause of long-run growth. In: Aghion, P., and S. Durlauf, Eds. Handbook of Economic Growth, Amsterdam: Elsevier/North Holland, 6, 385-472.

Aghion, P., and O.J. Blanchard, 1994. On the speed of transition in Central Europe. NBER Macroeconomics Annual, 9, 283-330.

Agnello, L., Castro, V., Jalles, J.T., and R.M. Sousa, 2014a. Do debt crises boost financial reforms?. Organization for Economic Co-Operation and Development, mimeo.

Agnello, L., Castro, V., Jalles, J.T., and R.M. Sousa, 2014b. Fiscal consolidation and financial reforms. Organization for Economic Co-Operation and Development, mimeo.

Agnello, L., Castro, V., Jalles, J.T., and R.M. Sousa, 2014c. Fiscal adjustments, labour market flexibility and unemployment. Economics Letters, 124(2), 231-235.

Agnello, L., Castro, V., Jalles, J.T., and R.M. Sousa, 2014d. The impact of income inequality and fiscal stimuli on political (in)stability. Organization for Economic Co-Operation and Development, mimeo.

Agnello, L., Mallick, S.K., and R.M. Sousa, 2012. Financial reforms and income inequality. Economics Letters, 116(3), 583-587.

Akerlof, G., 1991. Procrastination and obedience. American Economic Review, 81, 1-19.

Alesina, A., and A. Drazen, 1991. Why are stabilizations delayed? American Economic Review, 81, 1170-1188. 
Andrews, D., Caldera-Sanchez, A., and A. Johansson, 2011. Housing markets and structural policies in OECD countries. Organization for Economic Co-Operation and Development, OECD Economics Department Working Paper, No. 836.

Babecky, J., and N.F. Campos, 2011. Does reform work? An econometric survey of the reform growth puzzle. Journal of Comparative Economics, 39, 140-158.

Bassanini, A., Nunziata, L., and D. Venn, 2009. Job protection legislation and productivity growth in OECD countries. Economic Policy, 24 (58), 349-402.

Bates, R., and A. Krueger, 1993. Generalizations arising from the country studies. In: Bates, R., and A. Krueger, (eds.). Political and economic interactions in economic policy reform: Evidence from eight countries. Oxford: Basil Blackwell.

Beck, T., Clarke, G., Groff, A., Keefer, P., and P. Walsh, 2001. New tools in comparative political economy: The database of political institutions. The World Bank Economic Review, 15(1), 165-176.

Bekaert, G., Harvey, C., and R. Lundblad, 2005. Does financial liberalization spur growth? Journal of Financial Economics, 77, 3-56.

Blanchard, O., DellAriccia, G., and P. Mauro, 2010. Rethinking macroeconomic policy. International Monetary Fund, IMF Staff Position Note SPN No. 3.

Boeri, T., Castanheira, M., Faini, R., and V. Galasso, 2006. Structural reforms without prejudices. Oxford: Oxford University Press.

Boeri, T., Garibaldi., P., and E. Moen, 2012. The labor market consequences of adverse financial shocks. Institute for the Study of Labor, IZA Discussion Paper No. 6826.

Bortolotti, B., and P. Pinotti, 2008. Delayed privatization. Public Choice, 136, 331-351.

Bortolotti, B., Fantini, M., and D. Siniscalco, 2003. Privatization around the world: evidence from panel data. Journal of Public Economics, 88, 305-332.

Bouis, R., Causa, O., Demmou, L., Duval, R., and A. Zdzienicka, 2012. The short term effects of structural reforms: An empirical analysis. Organization for Economic Co-Operation and Development, OECD Economics Department Working Paper No. 949.

Brezis, E.S., and T. Verdier, 2003. Political institutions and economic reforms in Central and Eastern Europe: a snowball effect. Economic Systems, 27, 289-311.

Bruno, M., 1986. Aggregate supply and demand factors in OECD unemployment: An update. Economica, 53, 35-52.

Bruno, M., and W. Easterly, 1996. Inflation's children: Tales of crises that beget reforms. American Economic Review, 86(2), 213-217. 
Buera, F.J., Monge-Naranjo, A., and G.E. Primiceri, 2011. Learning the wealth of nations. Econometrica, 79(1), 1-45.

Campos, N.F., and F. Coricelli, 2012. Financial liberalization and reversals: political and economic determinants. Economic Policy, 27(71), 483-513.

Campos, N.F., and R. Horváth, 2012a. Reform redux: Measurement, determinants and growth implications. European Journal of Political Economy, 28, 227-237.

Campos, N.F., and R. Horváth, 2012b. On the reversibility of structural reforms. Economics Letters, 117, 217-219.

Campos, N.F., Hsiao, C., and J.B. Nugent, 2010. Crises, what crises? New evidence on the relative roles of political and economic crises in begetting reforms. The Journal of Development Studies, 46(10), 1670-1691.

Case, A.C., Hines, Jr., J.R. and H.S. Rosen. 1993. Budget spillovers and fiscal policy interdependence: Evidence from the States. Journal of Public Economics, 52(3), 285-307.

Cavelaars, P.A.D., 2003. Does competition enhancement have permanent inflation effects? Kyklos, 56(1), 69-94.

Chang, R., 2001. Commitment, coordination failures, and delayed reforms. Journal of Monetary Economics, 47, 123-144.

Clemens, M.A., and J.G. Williamson, 2004. Why did the tariff-growth correlation reverse after 1950? Journal of Economic Growth, 9(1), 5-46.

Conway, P., and G. Nicoletti, 2006. Product market regulation in the non-manufacturing sectors of OECD countries: Measurement and highlights. Organization for Economic CoOperation and Development, OECD Economics Department Working Paper No. 530.

Correa-Lopez, M., Garcia-Serrador, A., and C. Mingorance-Arnaiz, 2013. Product market competition, monetary policy regimes and inflation dynamics: Evidence from a panel of OECD countries. Oxford Bulletin of Economics and Statistics, forthcoming.

De Haan, J., and J.-E. Sturm, 1997. Political and economic determinants of OECD budget deficits and government expenditures: A reinvestigation. European Journal of Political Economy, 13, 739-750.

de Jong, E., and C. Bogmans, 2011. Does corruption discourage international trade? European Journal of Political Economy, 27, 385-398.

Dewatripont, M., and G. Roland, 1995. The design of reform packages under uncertainty. American Economic Review, 85, 1207-1223.

Dollar, D., and J. Svensson, 2000. What explains the success or failure of structural adjustment programs? The Economic Journal, 110, 894-917. 
Drazen, A., 2000. Political economy in macroeconomics. Princeton: Princeton University Press.

Drazen, A., and W. Easterly, 2001. Do crises induce reform? Simple empirical tests of conventional wisdom., Economics and Politics, 13(2), 129-157.

Drazen, A., and V. Grilli, 1993. The benefit of crises for economic reforms. American Economic Review, 83(3), 598-607.

Dreher, A., 2006. Does globalization affect growth? Evidence from a new index of globalization. Applied Economics, 38(10), 1091-1110.

Duval, R., 2008. Is there a role for macroeconomic policy in fostering structural reforms? Panel evidence from OECD countries over the past two decades. European Journal of Political Economy, 24, 491-502.

Easterly, W., and S. Fischer, 2000. Inflation and the poor. National Bureau of Economic Research, NBER Working Paper 2335.

Efendic, A., Pugh, G., and N. Adnett, 2011. Institutions and economic performance: a metaregression analysis. European Journal of Political Economy, 27, 586-599.

Eggertsson, T., 2005. Imperfect institutions, possibilities and limits of reform. University of Michigan Press, Ann Arbor.

Eichengreen, B., and C. Wyplosz, 1998. The stability pact: more than a minor nuisance? Economic Policy, 26, 65-113.

Elhorst, P., Zandberg, E., J. De Haan, 2013. The impact The Impact of interaction effects among neighbouring countries on financial liberalization and reform: A dynamic spatial panel data approach. Spatial Economic Analysis, 8(3), 293-313.Elmeskov, J., Martin, J., and S. Scarpetta, 1998. Key lessons for labour market reforms: Evidence from OECD countries' experiences. Stockholm: Economic Council of Sweden, IVA.

Fernandez, R., and D. Rodrik, 1991. Resistance of reform: status quo bias in the presence of individual-specific uncertainty. American Economic Review, 81, 1146-1155.

Fernández-Arias, E., and P. Montiel, 2001. Reform and growth in Latin America: All pain, no gain? IMF Staff Papers, 48(3), 522-546.

Fidrmuc, J., 2003. Economic reform, democracy and growth during post-communist transition. European Journal of Political Economy, 19(3), 583-604.

Fidrmuc, J., and E. Karaja, 2013. Uncertainty, informational spillovers and policy reform: A gravity model approach. European Journal of Political Economy, 32, 182-192.

Friedrichsen, J., and P. Zahn, 2014. Political support in hard times: Do people care about national welfare? European Journal of Political Economy, 35, 23-37. 
Gassebner, M., Gaston, N., and M. Lamla, 2011. The inverse domino effect: are economic reforms contagious? International Economic Review, 52, 183-200.

Golinelli, R., and R. Rovelli, 2013. Did growth and reforms increase citizens' support for the transition? European Journal of Political Economy, 30, 112-137.

Gomes, S., Jacquinot, P., Mohr, M., and M. Pisani, 2011. Structural reforms and macroeconomic performance in the Euro area countries: A model based assessment. European Central Bank, ECB Working Paper No. 1323.

Greene, W., 2012. Econometric analysis. 7th Ed. New Jersey, USA: Pearson Prentice Hall.

Grier, K., and D. Sutter, 2007. External influences on economic reform: Reform as a regional public good. European Journal of Political Economy, 23, 660-673.

Grindle, M. S., and J.W. Thomas, 1991. Public choices and policy change: The political economy of reform in developing countries. Baltimore and London: Johns Hopkins University Press.

Grossback, L.J., Nicholson-Crotty, S., and D.A. Peterson, 2004. Ideology and learning in policy diffusion. American Politics Research, 32(5), 521-545.

Haggard, S., and S. Maxfield, 1996. The political economy of financial internationalization in the developing world. International Organization, 50, 35-68.

Haggard, S., and R.R. Kaufman, 1992. The politics of economic adjustment: International constraints, distributive conflicts, and the State. Princeton: Princeton University Press.

Haggard, S., and S. Webb, 1994. Voting for reform: democracy, political liberalization and economic adjustment. New York. Oxford University Press.

Harberger, A., 1993. The search for relevance in economics. American Economic Review, 83, $1-17$.

Henry, P. B., 2007. Capital account liberalization: Theory, evidence, and speculation. Journal of Economic Literature, 45(4), 887-935.

Holden, S., 1994. Wage bargaining and nominal rigidities. European Economic Review, 38, 1021-1039.

Holden, S., 2004. The costs of price stability: downward nominal wage rigidity in Europe. Economica, 71(82), 183-208.

Huang, Y., 2009. The political economy of financial reform: are Abiad and Mody right? Journal of Applied Econometrics, 24, 1207-1213.

IMF, 2004. Fostering structural reforms in industrial countries. World Economic Outlook: Advancing Structural Reforms. Washigton, DC, International Monetary Fund.

Jong-A-Pin, R., and J. De Haan, 2007. Political regime change, economic reform and growth accelerations. CESifo Working Paper No. 1905. 
Keeler, J. T. 1993. New perspectives on democratic reform. Comparative Political Studies, 25(4), 427-432.

Koedijk, K., and J. Kremers, 1996. Market opening, regulation and growth in Europe. Economic Policy, 11(23), 443-467.

Kose, A., and E. Prasad, 2004. Liberalizing capital. Finance and Development. 50. Washington DC: International Monetary Fund.

Krueger, A., 1993. Political economy of policy reform in developing countries. Cambridge MA and London: MIT Press.

Lavigne, R., 2011. The political and institutional determinants of fiscal adjustment: Entering and exiting fiscal distress. European Journal of Political Economy, 27, 17-35.

Levchenko, A.A., Lewis, L.T., and L.L. Tesar, 2010. The collapse of international trade during the 2008-09 crisis: In search of the smoking gun. IMF Economic Review, 58(2), 214-253.

Lora, E., 2000. What makes reforms likely? Timing and sequencing of structural reforms in Latin America. Inter-American Development Bank, Working Paper No. 424.

Lora, E., Olivera, M., 2004. What makes reforms likely: Political economy determinants of reforms in Latin America. Journal of Applied Economics, 7(1), 99-135.

Meseguer, C., 2006. Learning and economic policy choices. European Journal of Political Economy, 22, 156-178.

Messina, J., Du Caju, P., Duarte, C. F., Lynggard Hansen, N., and M. Izquierdo, 2010. The incidence of nominal and real wage rigidity: An individual based sectoral approach. Banco de España, Documento de Trabajo No. 1022.

Mierau, J., Jong-A-Pin, R., and J. De Haan, 2007. Do political variables influence fiscal adjustment decisions? New empirical evidence. Public Choice, 133, 297-319.

Neiss, K., 2001. The markup and inflation: Evidence in OECD countries. Canadian Journal of Economics, 34(2), 570-587.

Nelson, J., 1990. Economic crisis and policy choice: The politics of adjustment in the Third World. Princeton: Princeton University Press.

Neri, M., 1995. Sobre a mesuração dos salários reais em alta inflação. Pesquisa $e$ Planejamento Econômico, 25(3), 497-525.

Nicoletti, G., and S. Scarpetta, 2003. Regulation, productivity and growth: OECD evidence. Economic Policy, 18(36), 9-72.

OECD, 2010. Economic policy reforms 2010: Going for Growth. Paris: OECD Publishing. 
Persson, T., and G. Tabellini, 2000. Political economics and public finance. In: Auerbach, A.J., and M. Feldstein, (Eds.). Handbook of Public Economics, 3, North-Holland, Amsterdam, 1551-1581.

Pitlik, H., and S. Wirth, 2003. Do crises promote the extent of economic liberalization? An empirical test. European Journal of Political Economy, 19(3), 565-581.

Ranciere, R., Tornell, A., and F. Westermann, 2006. Decomposing the effects of financial liberalization: Crises vs. growth. Journal of Banking and Finance, 30, 3331-3348.

Reinhart, C.M., and K.S. Rogoff, 2011. From financial crash to debt crisis. American Economic Review, 101(5), 1676-1706.

Roberts, B.M., and M.A. Saeed, 2012. Privatizations around the world: economic or political determinants? Econonomic and Politics, 24, 47-71.

Rodrik, D., 1994. The rush to free trade in the developing world: Why so late? Why now? Will it last? In: Haggard, S., and S. B. Webb, Eds.. Voting for reform: Democracy, political liberalization, and economic adjustment, Washington, DC: World Bank.

Rodrik, D., 1996. Understanding economic policy reform. Journal of Economic Literature, 34(1), 9-41.

Rodrik, D., 2000. Participatory politics, social cooperation, and economic stability. American Economic Review, Papers and Proceedings, 90, 140-144.

Romer, C.D., and D.H. Romer, 1999. Monetary policy and the well-being of the poor. Federal Reserve Bank of Kansas City Economic Review, 21-49.

Roubini, N., and J. Sachs, 1989a. Political and economic determinants of budget deficits in the industrial democracies. European Economic Review, 33, 903-933.

Roubini, N., and J. Sachs, 1989b. Government spending and budget deficits in the industrial countries. Economic Policy, 8, 99-132.

Saint-Paul, G., 2000. The Political Economy of Labor Market Institutions. Oxford University Press, Oxford.

Saint-Paul, G., 2004. Why are European countries diverging in their unemployment experience? Journal of Economic Perspectives, 18, 49-68.

Schindler, M., 2009. Measuring financial integration: A new dataset. IMF Staff Papers, 56, $222-238$.

Shehzad, C.T., and J. De Haan, 2009. Financial reform and banking crises. CESifo Working Paper No. 2870.

Simmons, B.A., and Z. Elkins, 2004. The globalization of liberalization: Policy diffusion in the international political economy. American Political Science Review, 98, 171-189. 
Svensson, J., 2000. When is foreign aid policy credible? Aid dependence and conditionality. Journal of Development Economics, 61(1), 61-84.

Tavares, S.C., 2007. Do rapid political and trade liberalizations increase corruption? European Journal of Political Economy, 23, 1053-1076.

Tommasi, M., and A. Velasco, 1996. Where are we in the political economy of reform? Journal of Policy Reform, 1, 187-238.

Tornell, A., 1998. Reform from within. National Bureau of Economic Research, NBER Working Paper No. 6497.

Toye, J., 1995. The new institutional economics and its implications for development theory. In: Harris, J., Hunter, J., and C. M. Lewis, (Eds.). The New Institutional Economics and Third World Development. Routledge, London, 49-68.

Volden, C., 2006. States as policy laboratories: Emulating success in the children's health insurance program. American Journal of Political Science, 50(2), 294-312.

Volden, C., Ting, M.M., and D.P. Carpenter, 2008. A formal model of learning and policy diffusion. American Political Science Review, 102(3), 319-332.

Wiese, R., 2014. What triggers reforms in OECD countries? Improved reform measurement and evidence from the healthcare sector. European Journal of Political Economy, 34, 332352.

Williamson, J., 1994. The political economy of policy reform. Washington, DC: Institute for International Economics.

Williamson, J., and S. Haggard, 1994. The political conditions for economic reform. In: Williamson, J. (Ed.). The political economy of policy reform, 525-596. Washington, DC: Institute for International Economics

Wooldridge, J., 2002. Econometric analysis of cross section and panel data. Cambridge, MA: MIT Press.

Zandberg, E., De Haan, J., and J.P. Elhorst, 2012. The political economy of financial reform: How robust are Huang's findings? Journal of Applied Econometrics, 27, 695-699. 


\section{List of Tables}

Table 1: List of countries included in the sample by set of regressions.

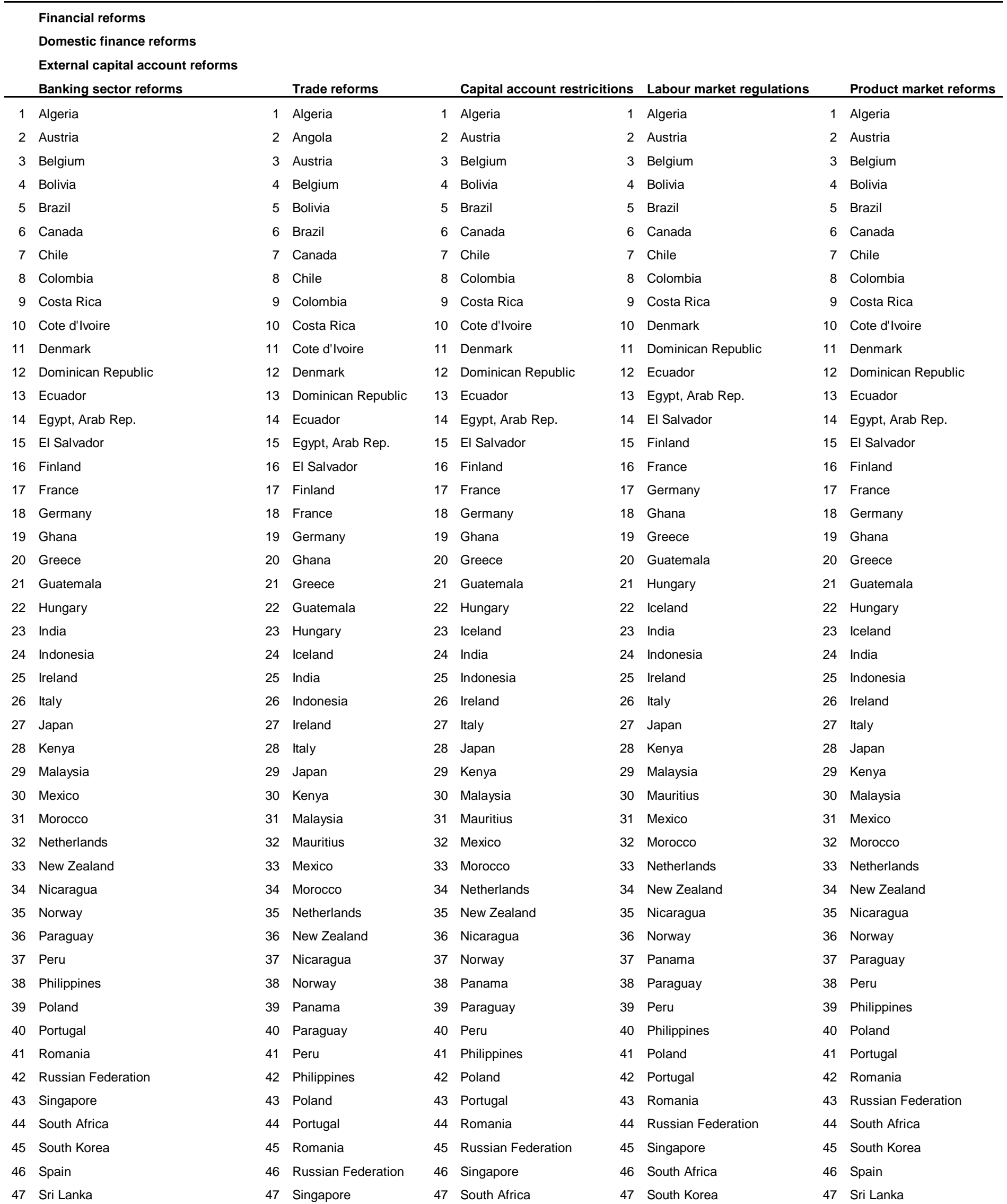


(cont.)

$\begin{array}{ll}48 & \text { Sweden } \\ 49 & \text { Switzerland } \\ 50 & \text { Thailand } \\ 51 & \text { Tunisia } \\ 52 & \text { Turkey } \\ 53 & \text { United States } \\ 54 & \text { Venezuela, RB } \\ 55 & \text { Zimbabwe }\end{array}$

48 South Africa

49 South Korea

50 Spain

51 Sri Lanka

52 Sweden

53 Switzerland

54 Thailand

55 Tunisia

56 Turkey

57 United States

58 Venezuela, RB

59 Zambia

60 Zimbabwe

$\begin{array}{ll}48 & \text { South Korea } \\ 49 & \text { Spain } \\ 50 & \text { Sri Lanka } \\ 51 & \text { Sweden } \\ 52 & \text { Switzerland } \\ 53 & \text { Thailand } \\ 54 & \text { Tunisia } \\ 55 & \text { Turkey } \\ 56 & \text { United States } \\ 57 & \text { Venezuela, RB } \\ 58 & \text { Zambia } \\ 59 & \text { Zimbabwe }\end{array}$

48 Spain

49 Sri Lanka

50 Sweden

51 Switzerland

52 Thailand

53 Tunisia

54 Turkey

55 United States

56 Venezuela, RB

57 Zambia
48 Sweden

49 Switzerland

50 Thailand

51 Tunisia

52 Turkey

53 United States

54 Venezuela, RB

55 Zimbabwe 
Table 2: Number of structural reforms and their relative importance.

\begin{tabular}{lcc}
\hline Structural Reforms & Number & Relative importance (\%) \\
\hline Financial reforms & 345 & $16.8 \%$ \\
Domestic finance reforms & 340 & $16.6 \%$ \\
External capital account reforms & 130 & $6.3 \%$ \\
Banking sector reforms & 328 & $16.0 \%$ \\
Trade reforms & 279 & $13.6 \%$ \\
Capital account restrictions & 188 & $9.2 \%$ \\
Labour market regulations & 233 & $11.4 \%$ \\
Product market reforms & 207 & $10.1 \%$ \\
\hline Total & 2050 & $100 \%$ \\
\hline
\end{tabular}


Table 3: The determinants of financial reforms.

\begin{tabular}{|c|c|c|c|c|c|c|c|}
\hline & (1) & (2) & (3) & (4) & (5) & (6) & (7) \\
\hline \multirow[t]{2}{*}{ Recession } & $0.429 * *$ & $0.446 * *$ & $0.445^{* *}$ & & $0.441 * *$ & $0.873 * * *$ & 0.126 \\
\hline & $(0.217)$ & $(0.199)$ & $(0.213)$ & & $(0.216)$ & $(0.327)$ & $(0.284)$ \\
\hline \multirow[t]{2}{*}{ Globalisation } & $0.096 * *$ & $0.096 * *$ & $0.098 * *$ & $0.097 * *$ & $0.096 * *$ & 0.014 & $0.161 * * *$ \\
\hline & $(0.039)$ & $(0.037)$ & $(0.039)$ & $(0.039)$ & $(0.039)$ & $(0.061)$ & $(0.053)$ \\
\hline \multirow[t]{2}{*}{ Gini } & $0.072 *$ & 0.062 & $0.073 *$ & $0.076 *$ & $0.072 *$ & 0.085 & 0.064 \\
\hline & $(0.043)$ & $(0.041)$ & $(0.043)$ & $(0.043)$ & $(0.043)$ & $(0.067)$ & $(0.057)$ \\
\hline \multirow[t]{2}{*}{ Fractionalisation } & 0.657 & & 0.800 & 0.763 & 0.753 & 1.652 & 0.416 \\
\hline & $(1.041)$ & & $(1.034)$ & $(1.046)$ & (1.033) & $(2.176)$ & $(1.224)$ \\
\hline \multirow[t]{2}{*}{ Domestic debt crisis } & -0.572 & & & & & & \\
\hline & $(0.449)$ & & & & & & \\
\hline \multirow{2}{*}{ External debt crisis } & $0.485^{*}$ & & $0.519 * *$ & $0.510 * *$ & $0.512 * *$ & 0.184 & $0.541 * *$ \\
\hline & $(0.249)$ & & $(0.235)$ & $(0.234)$ & $(0.237)$ & $(0.682)$ & $(0.251)$ \\
\hline \multirow[t]{2}{*}{ Currency crisis } & 0.005 & & & & & & \\
\hline & $(0.206)$ & & & & & & \\
\hline \multirow[t]{2}{*}{ Inflation crisis } & 0.326 & & & & & & \\
\hline & $(0.249)$ & & & & & & \\
\hline \multirow[t]{2}{*}{ Banking crisis } & $0.482 * * *$ & & $0.485 * * *$ & $0.513 * * *$ & $0.471 * * *$ & 0.413 & $0.513^{* *}$ \\
\hline & $(0.171)$ & & $(0.170)$ & $(0.169)$ & $(0.170)$ & $(0.282)$ & $(0.218)$ \\
\hline \multirow[t]{2}{*}{ Real GDP growth } & & & & -0.019 & & & \\
\hline & & & & $(0.024)$ & & & \\
\hline \multirow[t]{2}{*}{ Real GDP growth squared } & & & & 0.001 & & & \\
\hline & & & & $(0.003)$ & & & \\
\hline \multirow[t]{2}{*}{ Inflation } & & & & & 0.000 & & \\
\hline & & & & & $(0.000)$ & & \\
\hline Observations & 1,103 & 1,165 & 1,103 & 1,103 & 1,096 & 518 & 585 \\
\hline log-likelihood & -522.7 & -572.8 & -524.4 & -523.8 & -520.5 & -225.3 & -295.6 \\
\hline pseudo-R2 & 0.0309 & 0.0122 & 0.0279 & 0.0290 & 0.0272 & 0.0313 & 0.0366 \\
\hline
\end{tabular}


Table 4: The determinants of domestic finance reforms.

\begin{tabular}{|c|c|c|c|c|c|c|c|}
\hline & (1) & (2) & (3) & (4) & (5) & (6) & (7) \\
\hline \multirow[t]{2}{*}{ Recession } & $0.378^{*}$ & $0.445 * *$ & $0.451 * *$ & & $0.422 *$ & $0.848 * * *$ & 0.165 \\
\hline & $(0.219)$ & $(0.212)$ & $(0.214)$ & & $(0.217)$ & $(0.322)$ & $(0.286)$ \\
\hline \multirow[t]{2}{*}{ Globalisation } & $0.091 * *$ & $0.092 * *$ & $0.096 * *$ & $0.095 * *$ & $0.096 * *$ & 0.020 & $0.151 * * *$ \\
\hline & $(0.039)$ & $(0.039)$ & $(0.039)$ & $(0.039)$ & $(0.039)$ & $(0.062)$ & $(0.053)$ \\
\hline \multirow[t]{2}{*}{ Gini } & $0.106^{* *}$ & $0.110 * *$ & $0.103 * *$ & $0.105 * *$ & $0.101 * *$ & 0.091 & $0.113 * *$ \\
\hline & $(0.044)$ & $(0.043)$ & $(0.043)$ & $(0.043)$ & $(0.044)$ & $(0.068)$ & $(0.057)$ \\
\hline \multirow[t]{2}{*}{ Fractionalisation } & 1.388 & 1.614 & 1.570 & 1.507 & 1.528 & 1.185 & 1.677 \\
\hline & $(1.087)$ & $(1.088)$ & (1.094) & $(1.110)$ & $(1.092)$ & $(2.147)$ & $(1.274)$ \\
\hline Domestic debt crisis & $\begin{array}{c}0.074 \\
(0.438)\end{array}$ & & & & & & \\
\hline \multirow[t]{2}{*}{ External debt crisis } & $0.604 * *$ & & $0.691 * * *$ & $0.681 * * *$ & $0.662 * * *$ & 0.437 & $0.706^{* * *}$ \\
\hline & $(0.252)$ & & $(0.238)$ & $(0.237)$ & $(0.241)$ & $(0.682)$ & $(0.255)$ \\
\hline \multirow[t]{2}{*}{ Currency crisis } & 0.089 & & & & & & \\
\hline & $(0.208)$ & & & & & & \\
\hline \multirow[t]{2}{*}{ Inflation crisis } & 0.194 & & & & & & \\
\hline & $(0.254)$ & & & & & & \\
\hline \multirow[t]{2}{*}{ Banking crisis } & 0.228 & & & & & & \\
\hline & $(0.176)$ & & & & & & \\
\hline \multirow[t]{2}{*}{ Real GDP growth } & & & & -0.021 & & & \\
\hline & & & & $(0.024)$ & & & \\
\hline \multirow[t]{2}{*}{ Real GDP growth squared } & & & & 0.002 & & & \\
\hline & & & & $(0.003)$ & & & \\
\hline Inflation & & & & & $\begin{array}{c}0.000 \\
(0.000)\end{array}$ & & \\
\hline Observations & 1,103 & 1,103 & 1,103 & 1,103 & 1,096 & 518 & 585 \\
\hline log-likelihood & -509.2 & -515.0 & -510.8 & -512.5 & -506.1 & -220.6 & -287.5 \\
\hline pseudo-R2 & 0.0294 & 0.0184 & 0.0264 & 0.0231 & 0.0273 & 0.0231 & 0.0379 \\
\hline
\end{tabular}

Notes: Standard errors in parentheses. $* * * \mathrm{p}<0.01, * * \mathrm{p}<0.05, * \mathrm{p}<0.1$. pseudo-R2 $=1-\operatorname{logL} / \operatorname{logL0}$, where $\mathrm{L}$ is the likelihood of the model and L0 is the likelihood of the model without regressors. 
Table 5: The determinants of external capital account reforms.

\begin{tabular}{|c|c|c|c|c|c|c|c|}
\hline & (1) & (2) & (3) & (4) & (5) & (6) & (7) \\
\hline \multirow[t]{2}{*}{ Recession } & $0.616^{*}$ & $0.763 * *$ & $0.579 *$ & & 0.520 & -0.106 & $0.793 * *$ \\
\hline & $(0.324)$ & $(0.309)$ & $(0.316)$ & & $(0.324)$ & $(0.686)$ & $(0.376)$ \\
\hline \multirow{2}{*}{ Globalisation } & 0.034 & 0.051 & 0.032 & 0.028 & 0.037 & -0.083 & 0.071 \\
\hline & $(0.064)$ & $(0.064)$ & $(0.064)$ & $(0.064)$ & $(0.064)$ & $(0.128)$ & $(0.074)$ \\
\hline \multirow[t]{2}{*}{ Gini } & 0.080 & 0.068 & 0.074 & 0.083 & 0.060 & 0.102 & 0.072 \\
\hline & $(0.073)$ & $(0.072)$ & $(0.072)$ & $(0.072)$ & $(0.072)$ & $(0.131)$ & $(0.087)$ \\
\hline \multirow[t]{2}{*}{ Fractionalisation } & -0.502 & 0.144 & -0.434 & -0.627 & -0.435 & 4.245 & -2.411 \\
\hline & $(1.440)$ & $(1.411)$ & $(1.428)$ & $(1.457)$ & $(1.430)$ & (3.547) & $(1.775)$ \\
\hline \multirow[t]{2}{*}{ Domestic debt crisis } & -0.505 & & & & & & \\
\hline & $(0.682)$ & & & & & & \\
\hline \multirow[t]{2}{*}{ External debt crisis } & -0.057 & & & & & & \\
\hline & $(0.401)$ & & & & & & \\
\hline \multirow[t]{2}{*}{ Currency crisis } & -0.163 & & & & & & \\
\hline & $(0.330)$ & & & & & & \\
\hline \multirow[t]{2}{*}{ Inflation crisis } & $0.955 * *$ & & $0.832 * *$ & $0.839 * *$ & $0.867 * *$ & $1.297 *$ & $0.698 *$ \\
\hline & $(0.387)$ & & $(0.353)$ & $(0.352)$ & $(0.364)$ & $(0.751)$ & $(0.402)$ \\
\hline \multirow[t]{2}{*}{ Banking crisis } & $0.591 * *$ & & $0.569 * *$ & $0.549 * *$ & $0.488 *$ & 0.474 & $0.718 * *$ \\
\hline & $(0.273)$ & & $(0.272)$ & $(0.275)$ & $(0.276)$ & $(0.549)$ & $(0.324)$ \\
\hline \multirow[t]{2}{*}{ Real GDP growth } & & & & $-0.066 * *$ & & & \\
\hline & & & & $(0.031)$ & & & \\
\hline \multirow[t]{2}{*}{ Real GDP growth squared } & & & & -0.002 & & & \\
\hline & & & & $(0.005)$ & & & \\
\hline \multirow[t]{2}{*}{ Inflation } & & & & & 0.000 & & \\
\hline & & & & & $(0.000)$ & & \\
\hline Observations & 879 & 879 & 879 & 879 & 872 & 354 & 525 \\
\hline log-likelihood & -203.3 & -209.1 & -203.8 & -203.0 & -200.5 & -65.03 & -135.1 \\
\hline pseudo-R2 & 0.0451 & 0.0174 & 0.0427 & 0.0464 & 0.0460 & 0.0590 & 0.0599 \\
\hline
\end{tabular}

Notes: Standard errors in parentheses. ${ }^{* * *} \mathrm{p}<0.01, * * \mathrm{p}<0.05, * \mathrm{p}<0.1$. pseudo-R2 $=1-\log \mathrm{L} / \log \mathrm{L} 0$, where $\mathrm{L}$ is the likelihood of the model and L0 is the likelihood of the model without regressors. 
Table 6: The determinants of banking sector reforms.

\begin{tabular}{|c|c|c|c|c|c|c|c|}
\hline & (1) & (2) & (3) & (4) & (5) & (6) & (7) \\
\hline Recession & $\begin{array}{c}0.563 * * \\
(0.221)\end{array}$ & $\begin{array}{c}0.603 * * * \\
(0.214)\end{array}$ & $\begin{array}{c}0.610 * * * \\
(0.216)\end{array}$ & & $\begin{array}{c}0.579 * * * \\
(0.219)\end{array}$ & $\begin{array}{c}1.052 * * * \\
(0.322)\end{array}$ & $\begin{array}{c}0.300 \\
(0.291)\end{array}$ \\
\hline Globalisation & $\begin{array}{c}0.082 * * \\
(0.040)\end{array}$ & $\begin{array}{c}0.082 * * \\
(0.040)\end{array}$ & $\begin{array}{c}0.086 * * \\
(0.040)\end{array}$ & $\begin{array}{c}0.084 * * \\
(0.040)\end{array}$ & $\begin{array}{c}0.086 * * \\
(0.041)\end{array}$ & $\begin{array}{c}0.024 \\
(0.064)\end{array}$ & $\begin{array}{c}0.130 * * \\
(0.054)\end{array}$ \\
\hline Gini & $\begin{array}{l}0.085^{*} \\
(0.045)\end{array}$ & $\begin{array}{c}0.091 * * \\
(0.044)\end{array}$ & $\begin{array}{l}0.084 * \\
(0.044)\end{array}$ & $\begin{array}{c}0.088 * * \\
(0.044)\end{array}$ & $\begin{array}{l}0.081 * \\
(0.044)\end{array}$ & $\begin{array}{c}0.023 \\
(0.069)\end{array}$ & $\begin{array}{c}0.130 * * \\
(0.060)\end{array}$ \\
\hline Fractionalisation & $\begin{array}{c}1.498 \\
(1.116)\end{array}$ & $\begin{array}{c}1.647 \\
(1.115)\end{array}$ & $\begin{array}{c}1.617 \\
(1.118)\end{array}$ & $\begin{array}{c}1.496 \\
(1.140)\end{array}$ & $\begin{array}{c}1.572 \\
(1.117)\end{array}$ & $\begin{array}{c}0.706 \\
(2.080)\end{array}$ & $\begin{array}{c}1.983 \\
(1.313)\end{array}$ \\
\hline Domestic debt crisis & $\begin{array}{c}0.061 \\
(0.450)\end{array}$ & & & & & & \\
\hline External debt crisis & $\begin{array}{c}0.563 * * \\
(0.260)\end{array}$ & & $\begin{array}{c}0.621 * * \\
(0.246)\end{array}$ & $\begin{array}{r}0.604 * * \\
(0.244)\end{array}$ & $\begin{array}{c}0.590 * * \\
(0.249)\end{array}$ & $\begin{array}{c}0.256 \\
(0.710)\end{array}$ & $\begin{array}{c}0.653 * * \\
(0.264)\end{array}$ \\
\hline Currency crisis & $\begin{array}{c}0.054 \\
(0.216)\end{array}$ & & & & & & \\
\hline Inflation crisis & $\begin{array}{c}0.130 \\
(0.264)\end{array}$ & & & & & & \\
\hline Banking crisis & $\begin{array}{c}0.149 \\
(0.183)\end{array}$ & & & & & & \\
\hline Real GDP growth & & & & $\begin{array}{c}-0.034 \\
(0.024)\end{array}$ & & & \\
\hline Real GDP growth squared & & & & $\begin{array}{c}0.002 \\
(0.003)\end{array}$ & & & \\
\hline Inflation & & & & & $\begin{array}{c}0.000 \\
(0.000) \\
\end{array}$ & & \\
\hline Observations & 1,103 & 1,103 & 1,103 & 1,103 & 1,096 & 518 & 585 \\
\hline log-likelihood & -481.1 & -484.9 & -481.7 & -484.6 & -477.0 & -207.3 & -271.2 \\
\hline pseudo-R2 & 0.0270 & 0.0193 & 0.0257 & 0.0200 & 0.0266 & 0.0260 & 0.0369 \\
\hline
\end{tabular}

Notes: Standard errors in parentheses. ${ }^{* * *} \mathrm{p}<0.01, * * \mathrm{p}<0.05,{ }^{*} \mathrm{p}<0.1$. pseudo-R2 $=1-\log \mathrm{L} / \operatorname{logL0}$, where $\mathrm{L}$ is the likelihood of the model and L0 is the likelihood of the model without regressors. 
Table 7: The determinants of trade reforms.

\begin{tabular}{|c|c|c|c|c|c|c|c|}
\hline & (1) & (2) & (3) & (4) & $(5)$ & $(6)$ & $(7)$ \\
\hline Recession & $\begin{array}{c}0.682 * * \\
(0.266)\end{array}$ & $\begin{array}{c}0.734 * * * \\
(0.260)\end{array}$ & $\begin{array}{c}0.734 * * * \\
(0.260)\end{array}$ & & $\begin{array}{c}0.612 * * \\
(0.268)\end{array}$ & $\begin{array}{c}0.291 \\
(0.617)\end{array}$ & $\begin{array}{c}0.877 * * * \\
(0.293)\end{array}$ \\
\hline Globalisation & $\begin{array}{l}-0.001 \\
(0.052)\end{array}$ & $\begin{array}{c}0.005 \\
(0.051)\end{array}$ & $\begin{array}{c}0.005 \\
(0.051)\end{array}$ & $\begin{array}{c}0.001 \\
(0.051)\end{array}$ & $\begin{array}{c}0.000 \\
(0.051)\end{array}$ & $\begin{array}{c}-0.325^{* *} \\
(0.134)\end{array}$ & $\begin{array}{c}0.062 \\
(0.055)\end{array}$ \\
\hline Gini & $\begin{array}{c}0.002 \\
(0.053)\end{array}$ & $\begin{array}{c}0.004 \\
(0.053)\end{array}$ & $\begin{array}{c}0.004 \\
(0.053)\end{array}$ & $\begin{array}{c}0.002 \\
(0.054)\end{array}$ & $\begin{array}{l}-0.011 \\
(0.053)\end{array}$ & $\begin{array}{c}0.236 \\
(0.154)\end{array}$ & $\begin{array}{l}-0.030 \\
(0.058)\end{array}$ \\
\hline Fractionalisation & $\begin{array}{c}0.966 \\
(1.168)\end{array}$ & $\begin{array}{c}1.186 \\
(1.156)\end{array}$ & $\begin{array}{c}1.186 \\
(1.156)\end{array}$ & $\begin{array}{c}0.934 \\
(1.197)\end{array}$ & $\begin{array}{c}1.221 \\
(1.155)\end{array}$ & $\begin{array}{l}-0.052 \\
(2.986)\end{array}$ & $\begin{array}{c}1.439 \\
(1.317)\end{array}$ \\
\hline Domestic debt crisis & $\begin{array}{c}0.169 \\
(0.476)\end{array}$ & & & & & & \\
\hline External debt crisis & $\begin{array}{c}0.370 \\
(0.283)\end{array}$ & & & & & & \\
\hline Currency crisis & $\begin{array}{c}0.039 \\
(0.253)\end{array}$ & & & & & & \\
\hline Inflation crisis & $\begin{array}{c}0.084 \\
(0.301)\end{array}$ & & & & & & \\
\hline Banking crisis & $\begin{array}{c}0.352 \\
(0.230)\end{array}$ & & & & & & \\
\hline Real GDP growth & & & & $\begin{array}{l}-0.027 \\
(0.025)\end{array}$ & & & \\
\hline Real GDP growth squared & & & & $\begin{array}{c}0.006 * * \\
(0.003)\end{array}$ & & & \\
\hline Inflation & & & & & $\begin{array}{c}0.001 * * \\
(0.000)\end{array}$ & & \\
\hline Observations & 846 & 846 & 846 & 846 & 842 & 250 & 596 \\
\hline log-likelihood & -302.8 & -305.4 & -305.4 & -306.8 & -296.9 & -61.62 & -238.2 \\
\hline pseudo-R2 & 0.0232 & 0.0147 & 0.0147 & 0.0102 & 0.0291 & 0.0631 & 0.0245 \\
\hline
\end{tabular}

Notes: Standard errors in parentheses. $* * * \mathrm{p}<0.01, * * \mathrm{p}<0.05, * \mathrm{p}<0.1$. pseudo-R2 $=1-\operatorname{logL} / \operatorname{logL0}$, where $\mathrm{L}$ is the likelihood of the model and L0 is the likelihood of the model without regressors. 
Table 8: The determinants of capital account restrictions.

\begin{tabular}{|c|c|c|c|c|c|c|c|}
\hline & (1) & (2) & (3) & (4) & (5) & (6) & (7) \\
\hline \multirow[t]{2}{*}{ Recession } & 0.419 & 0.467 & 0.467 & & 0.389 & 0.695 & 0.330 \\
\hline & $(0.296)$ & $(0.288)$ & $(0.288)$ & & $(0.296)$ & $(0.449)$ & $(0.377)$ \\
\hline \multirow[t]{2}{*}{ Globalisation } & -0.016 & -0.012 & -0.012 & -0.013 & 0.009 & 0.059 & -0.058 \\
\hline & $(0.058)$ & $(0.058)$ & $(0.058)$ & $(0.058)$ & $(0.058)$ & $(0.088)$ & $(0.075)$ \\
\hline \multirow[t]{2}{*}{ Gini } & 0.035 & 0.041 & 0.041 & 0.046 & 0.035 & -0.089 & 0.107 \\
\hline & $(0.058)$ & $(0.058)$ & $(0.058)$ & $(0.058)$ & $(0.058)$ & $(0.102)$ & $(0.073)$ \\
\hline \multirow[t]{2}{*}{ Fractionalisation } & $2.160 *$ & $2.392 * *$ & $2.392 * *$ & $2.393^{*}$ & $2.354 *$ & 3.417 & 2.211 \\
\hline & $(1.222)$ & $(1.210)$ & $(1.210)$ & $(1.226)$ & $(1.210)$ & $(2.464)$ & $(1.508)$ \\
\hline \multirow[t]{2}{*}{ Domestic debt crisis } & 0.369 & & & & & & \\
\hline & $(0.538)$ & & & & & & \\
\hline \multirow[t]{2}{*}{ External debt crisis } & 0.549 & & & & & & \\
\hline & $(0.354)$ & & & & & & \\
\hline \multirow[t]{2}{*}{ Currency crisis } & -0.232 & & & & & & \\
\hline & $(0.296)$ & & & & & & \\
\hline \multirow[t]{2}{*}{ Inflation crisis } & 0.372 & & & & & & \\
\hline & $(0.334)$ & & & & & & \\
\hline \multirow[t]{2}{*}{ Banking crisis } & 0.227 & & & & & & \\
\hline & $(0.253)$ & & & & & & \\
\hline \multirow[t]{2}{*}{ Real GDP growth } & & & & $-0.051^{*}$ & & & \\
\hline & & & & $(0.029)$ & & & \\
\hline \multirow[t]{2}{*}{ Real GDP growth squared } & & & & -0.003 & & & \\
\hline & & & & $(0.004)$ & & & \\
\hline \multirow[t]{2}{*}{ Inflation } & & & & & 0.000 & & \\
\hline & & & & & $(0.000)$ & & \\
\hline Observations & 1,113 & 1,113 & 1,113 & 1,113 & 1,106 & 498 & 615 \\
\hline log-likelihood & -280.6 & -284.0 & -284.0 & -283.0 & -280.1 & -119.2 & -162.8 \\
\hline pseudo-R2 & 0.0242 & 0.0124 & 0.0124 & 0.0160 & 0.0168 & 0.0248 & 0.0154 \\
\hline
\end{tabular}


Table 9: The determinants of labour market regulations.

\begin{tabular}{|c|c|c|c|c|c|c|c|}
\hline & (1) & (2) & (3) & (4) & (5) & (6) & (7) \\
\hline \multirow[t]{2}{*}{ Recession } & -0.219 & -0.358 & -0.358 & & -0.414 & -0.319 & -0.401 \\
\hline & $(0.578)$ & $(0.556)$ & $(0.556)$ & & $(0.567)$ & $(0.698)$ & $(0.911)$ \\
\hline \multirow[t]{2}{*}{ Globalisation } & -0.022 & -0.008 & -0.008 & 0.006 & -0.009 & -0.120 & 0.089 \\
\hline & $(0.074)$ & $(0.073)$ & $(0.073)$ & $(0.074)$ & $(0.073)$ & $(0.125)$ & $(0.100)$ \\
\hline \multirow[t]{2}{*}{ Gini } & -0.074 & -0.078 & -0.078 & -0.079 & -0.073 & -0.070 & -0.074 \\
\hline & $(0.114)$ & $(0.113)$ & $(0.113)$ & $(0.112)$ & $(0.112)$ & $(0.141)$ & $(0.191)$ \\
\hline \multirow[t]{2}{*}{ Fractionalisation } & 0.088 & 0.336 & 0.336 & 0.981 & 0.353 & 4.377 & -1.973 \\
\hline & $(2.167)$ & $(2.175)$ & $(2.175)$ & $(2.247)$ & $(2.191)$ & $(4.352)$ & $(2.634)$ \\
\hline \multirow[t]{2}{*}{ Domestic debt crisis } & 0.622 & & & & & & \\
\hline & $(1.476)$ & & & & & & \\
\hline \multirow[t]{2}{*}{ External debt crisis } & 1.175 & & & & & & \\
\hline & $(0.837)$ & & & & & & \\
\hline \multirow[t]{2}{*}{ Currency crisis } & 0.196 & & & & & & \\
\hline & $(0.408)$ & & & & & & \\
\hline \multirow[t]{2}{*}{ Inflation crisis } & -0.483 & & & & & & \\
\hline & $(0.692)$ & & & & & & \\
\hline \multirow{2}{*}{ Banking crisis } & -0.209 & & & & & & \\
\hline & $(0.583)$ & & & & & & \\
\hline \multirow[t]{2}{*}{ Real GDP growth } & & & & 0.071 & & & \\
\hline & & & & $(0.075)$ & & & \\
\hline \multirow[t]{2}{*}{ Real GDP growth squared } & & & & $-0.019 *$ & & & \\
\hline & & & & $(0.010)$ & & & \\
\hline Inflation & & & & & $\begin{array}{c}0.020 \\
(0.023)\end{array}$ & & \\
\hline Observations & 339 & 339 & 339 & 339 & 339 & 189 & 150 \\
\hline log-likelihood & -134.9 & -136.4 & -136.4 & -134.2 & -136.0 & -70.09 & -64.44 \\
\hline pseudo-R2 & 0.0146 & 0.00358 & 0.00358 & 0.0196 & 0.00665 & 0.0210 & 0.0138 \\
\hline
\end{tabular}


Table 10: The determinants of product market reforms.

\begin{tabular}{|c|c|c|c|c|c|c|c|}
\hline & (1) & (2) & (3) & (4) & (5) & (6) & (7) \\
\hline \multirow[t]{2}{*}{ Recession } & -0.484 & -0.414 & -0.414 & & -0.415 & -0.721 & -0.296 \\
\hline & $(0.351)$ & $(0.343)$ & $(0.343)$ & & $(0.348)$ & $(0.569)$ & $(0.462)$ \\
\hline \multirow[t]{2}{*}{ Globalisation } & 0.063 & 0.071 & 0.071 & 0.069 & 0.073 & 0.079 & 0.079 \\
\hline & $(0.052)$ & $(0.051)$ & $(0.051)$ & $(0.052)$ & $(0.052)$ & $(0.070)$ & $(0.077)$ \\
\hline \multirow[t]{2}{*}{ Gini } & 0.061 & 0.058 & 0.058 & 0.055 & 0.059 & -0.140 & $0.277 * * *$ \\
\hline & $(0.065)$ & $(0.065)$ & $(0.065)$ & $(0.064)$ & $(0.065)$ & $(0.092)$ & $(0.104)$ \\
\hline \multirow[t]{2}{*}{ Fractionalisation } & 1.214 & 1.362 & 1.362 & 1.185 & 1.382 & $4.154^{*}$ & -0.459 \\
\hline & $(1.445)$ & $(1.446)$ & $(1.446)$ & $(1.516)$ & $(1.445)$ & $(2.216)$ & $(2.106)$ \\
\hline \multirow[t]{2}{*}{ Domestic debt crisis } & 0.398 & & & & & & \\
\hline & $(0.599)$ & & & & & & \\
\hline \multirow[t]{2}{*}{ External debt crisis } & -0.290 & & & & & & \\
\hline & $(0.381)$ & & & & & & \\
\hline \multirow[t]{2}{*}{ Currency crisis } & 0.017 & & & & & & \\
\hline & $(0.291)$ & & & & & & \\
\hline \multirow[t]{2}{*}{ Inflation crisis } & 0.179 & & & & & & \\
\hline & $(0.357)$ & & & & & & \\
\hline \multirow[t]{2}{*}{ Banking crisis } & 0.196 & & & & & & \\
\hline & $(0.254)$ & & & & & & \\
\hline \multirow[t]{2}{*}{ Real GDP growth } & & & & 0.003 & & & \\
\hline & & & & $(0.034)$ & & & \\
\hline \multirow[t]{2}{*}{ Real GDP growth squared } & & & & 0.001 & & & \\
\hline & & & & $(0.005)$ & & & \\
\hline \multirow[t]{2}{*}{ Inflation } & & & & & 0.000 & & \\
\hline & & & & & $(0.000)$ & & \\
\hline Observations & 1,097 & 1,097 & 1,097 & 1,097 & 1,090 & 566 & 531 \\
\hline log-likelihood & -301.3 & -302.1 & -302.1 & -302.9 & -299.4 & -155.4 & -140.4 \\
\hline pseudo-R2 & 0.0109 & 0.00801 & 0.00801 & 0.00548 & 0.00821 & 0.0253 & 0.0326 \\
\hline
\end{tabular}

Notes: Standard errors in parentheses. *** $\mathrm{p}<0.01$, ** $\mathrm{p}<0.05, * \mathrm{p}<0.1$. pseudo-R2 $=1-$ $\log \mathrm{L} / \log \mathrm{L} 0$, where $\mathrm{L}$ is the likelihood of the model and $\mathrm{L} 0$ is the likelihood of the model without regressors. 
Table 11: The determinants of structural reversals.

\begin{tabular}{|c|c|c|c|c|c|c|c|c|}
\hline & $\begin{array}{c}\text { (1) } \\
\text { Financial } \\
\text { reforms }\end{array}$ & $\begin{array}{c}\text { (2) } \\
\text { Domestic } \\
\text { finance } \\
\text { reforms }\end{array}$ & $\begin{array}{c}\text { (3) } \\
\text { External capital } \\
\text { account } \\
\text { reforms }\end{array}$ & $\begin{array}{l}\text { (4) } \\
\text { Banking } \\
\text { sector } \\
\text { reforms }\end{array}$ & $\begin{array}{c}5) \\
\text { Trade } \\
\text { reforms }\end{array}$ & $\begin{array}{c}\text { (6) } \\
\text { Capital } \\
\text { account } \\
\text { restrictions }\end{array}$ & $\begin{array}{c}(7) \\
\text { Labour } \\
\text { market } \\
\text { regulations }\end{array}$ & $\begin{array}{l}(8) \\
\text { Product } \\
\text { market } \\
\text { reforms }\end{array}$ \\
\hline Recession & $\begin{array}{c}1.182 * * * \\
(0.432)\end{array}$ & $\begin{array}{l}0.855^{*} \\
(0.508)\end{array}$ & $\begin{array}{c}1.280 * * * \\
(0.455)\end{array}$ & $\begin{array}{l}0.842^{*} \\
(0.501)\end{array}$ & $\begin{array}{c}0.090 \\
(0.377)\end{array}$ & $\begin{array}{c}1.460 * * * \\
(0.428)\end{array}$ & $\begin{array}{c}0.108 \\
(0.459)\end{array}$ & $\begin{array}{c}-16.613 \\
(3816.004)\end{array}$ \\
\hline Globalisation & $\begin{array}{l}-0.145 \\
(0.101)\end{array}$ & $\begin{array}{l}-0.179 \\
(0.118)\end{array}$ & $\begin{array}{l}-0.046 \\
(0.127)\end{array}$ & $\begin{array}{l}-0.186 \\
(0.114)\end{array}$ & $\begin{array}{l}-0.069 \\
(0.073)\end{array}$ & $\begin{array}{c}0.083 \\
(0.114)\end{array}$ & $\begin{array}{c}0.012 \\
(0.060)\end{array}$ & $\begin{array}{c}0.496^{* *} \\
(0.215)\end{array}$ \\
\hline Gini & $\begin{array}{c}-0.319 * * * \\
(0.103)\end{array}$ & $\begin{array}{c}-0.253^{* *} \\
(0.100)\end{array}$ & $\begin{array}{l}-0.085 \\
(0.107)\end{array}$ & $\begin{array}{c}-0.243 * * \\
(0.098)\end{array}$ & $\begin{array}{l}-0.093 \\
(0.076)\end{array}$ & $\begin{array}{c}0.098 \\
(0.113)\end{array}$ & $\begin{array}{l}0.209^{*} \\
(0.111)\end{array}$ & $\begin{array}{l}-0.009 \\
(0.322)\end{array}$ \\
\hline Fractionalization & $\begin{array}{l}-1.133 \\
(2.307)\end{array}$ & $\begin{array}{l}-3.253 \\
(2.589)\end{array}$ & $\begin{array}{l}1.050 \\
(2.558)\end{array}$ & $\begin{array}{l}-4.126 \\
(2.520)\end{array}$ & $\begin{array}{c}-0.302 \\
(1.511)\end{array}$ & $\begin{array}{c}0.302 \\
(2.101)\end{array}$ & $\begin{array}{l}-1.041 \\
(1.808)\end{array}$ & $\begin{array}{c}13.130 \\
(16.649)\end{array}$ \\
\hline External debt crisis & $\begin{array}{l}-0.145 \\
(0.474)\end{array}$ & $\begin{array}{l}-0.095 \\
(0.536)\end{array}$ & & $\begin{array}{c}0.076 \\
(0.515)\end{array}$ & & & & \\
\hline Inflation crisis & & & $\begin{array}{c}0.175 \\
(0.491)\end{array}$ & & & & & \\
\hline Banking crisis & $\begin{array}{l}-0.136 \\
(0.374) \\
\end{array}$ & & $\begin{array}{r}0.330 \\
(0.418) \\
\end{array}$ & & & & & \\
\hline Observations & 634 & 480 & 451 & 505 & 663 & 498 & 360 & 136 \\
\hline log-likelihood & -113.1 & -86.28 & -82.91 & -91.58 & -178.8 & -90.04 & -171.6 & -13.06 \\
\hline pseudo-R2 & 0.0795 & 0.0698 & 0.0566 & 0.0700 & 0.00695 & 0.0637 & 0.0128 & 0.209 \\
\hline
\end{tabular}

Notes: Standard errors in parentheses. ${ }^{* * *} \mathrm{p}<0.01,{ }^{* *} \mathrm{p}<0.05,{ }^{*} \mathrm{p}<0.1$. pseudo-R $2=1-\log \mathrm{L} / \log \mathrm{L} 0$, where $\mathrm{L}$ is the likelihood of the model and L0 is the likelihood of the model without regressors. 
Table 12: The determinants of structural reforms - IV-Probit model estimation.

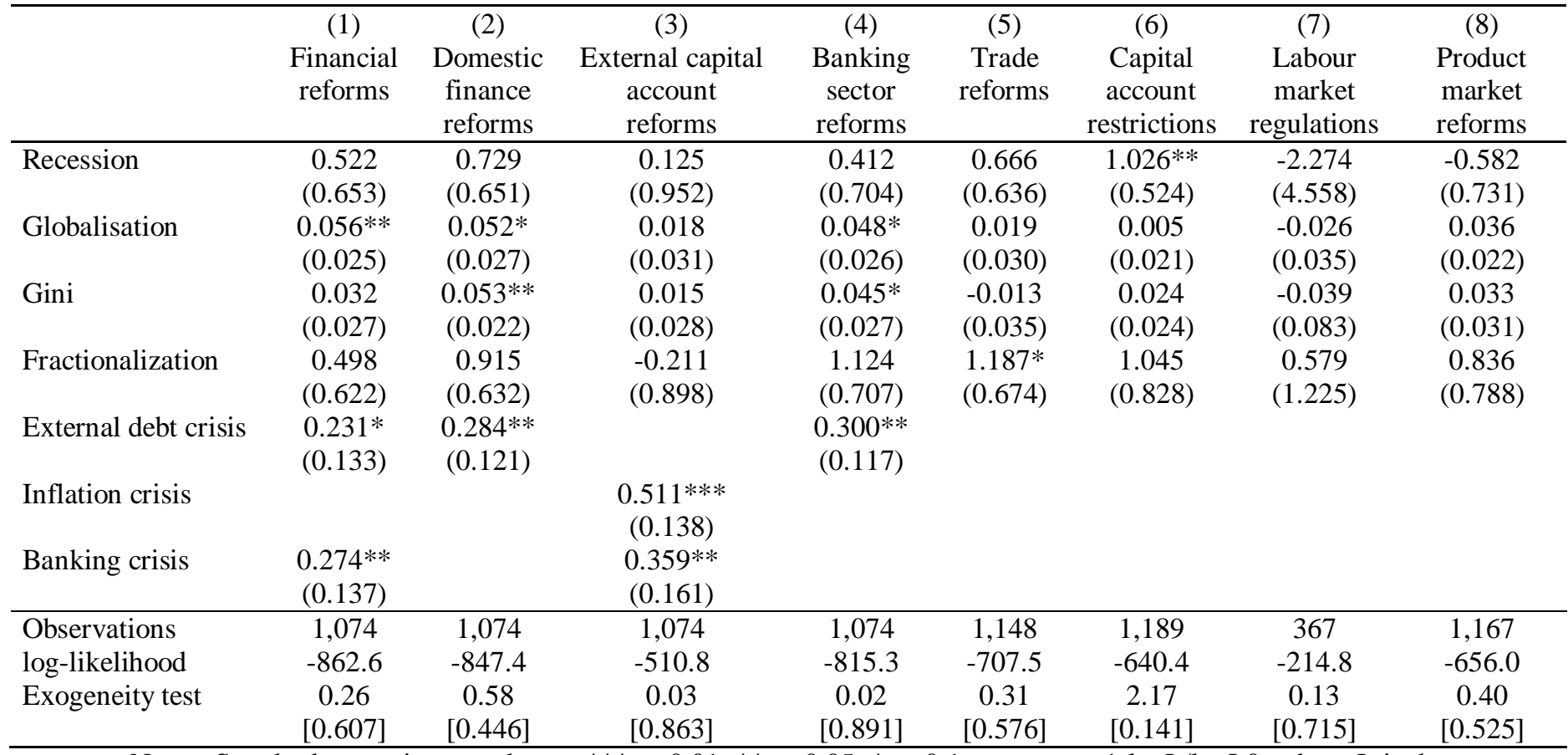

Notes: Standard errors in parentheses. *** $\mathrm{p}<0.01,{ }^{* *} \mathrm{p}<0.05, * \mathrm{p}<0.1$. pseudo- $\mathrm{R} 2=1-\log \mathrm{L} / \log \mathrm{L} 0$, where $\mathrm{L}$ is the likelihood of the model and L0 is the likelihood of the model without regressors. For the Wald test of exogeneity, we report the observed value and the respective $p$-value in square brackets. 